Z Badań nad Książką i Księgozbiorami Historycznymi 2021, t. 15, z. 2

\author{
Jakub Maciej Łubocki \\ Dział Sztuki Wydawniczej \\ Muzeum Narodowe we Wrocławiu \\ jakub.lubocki@mnwr.pl \\ (iD) 0000-0002-1957-0682 \\ https://doi.org/10.33077/uw.25448730.zbkh.2021.668
}

\title{
Czasopismo „Litera” (1966-1978) jako świadectwo XX-wiecznego dorobku polskiej myśli o typografii i liternictwie
}

\author{
Journal "Litera" (1966-1978) as an evidence \\ of $20^{\text {th }}$-century output of Polish thought \\ on typography and lettering
}

\begin{abstract}
Based on the review of the book "Lit[t]era Romana. Antologia tekstów z czasopisma Litera 1966-1978” (oprac. M. Marek-Łucka, A. Tomaszewski, Warszawa 2020) [“Lit[t]era Romana. Anthology of texts from the journal Litera 1966-1978" (compiled by Monika MarekŁucka, Andrzej Tomaszewski, Warsaw 2020)] and its publishing process, a formal and thematic description of the journal "Litera. Dodatek «Poligrafiki» poświęcony sprawom liternictwa, czcionek i matryc drukarskich" ["Letter. Supplement of "Poligrafika" devoted to the issues of lettering, typefaces and printing matrices"] (1966-1978) was made. This analysis, contains description of audience, scope, frequency, volume, circulation, price and number of articles with their topics, was enriched with description of the author's circle of articles, including the editor of the journal (Roman Tomaszewski) and the editors of the anthology. The whole was done to show the uniqueness of the journal "Litera" (which was phenomenon not only on the Polish, but also on the international arena of current information about printing and lettering) and its influence on Polish typography and lettering.
\end{abstract}

Key words: „Lit[t]era Romana. Antologia tekstów z czasopisma Litera 1966-1978” - „Litera. Dodatek «Poligrafiki» poświęcony sprawom liternictwa, czcionek i matryc drukarskich”- polish lettering - polish typography

Słowa kluczowe: „Lit[t]era Romana. Antologia tekstów z czasopisma Litera 1966-1978” „Litera. Dodatek «Poligrafiki» poświęcony sprawom liternictwa, czcionek i matryc drukarskich”polskie liternictwo - polska typografia 


\section{Wstęp}

Z ogromną satysfakcją należy przyjąć pojawienie się publikacji Lit[t]era Romana, będącej antologią najważniejszych tekstów opublikowanych na łamach czasopisma „Litera. Dodatku «Poligrafiki» poświęconego sprawom liternictwa, czcionek i matryc drukarskich". Przywraca ona nie tylko świadomość istnienia periodyku, ale przede wszystkim jego najistotniejsze treści. Można zapytać, w jakim celu powielać artykuły sprzed ponad 50 lat, które dotyczą dziedziny - zdawałoby się - archaicznej, może nawet technologicznie wymarłej? Mało kto zaprząta sobie dziś głowę kasztami, matrycami, gorącym składem czy drukarniami dziełowymi: wszak dziś wszystko dzieje się na ciekłokrystalicznym ekranie, a jeśli myślimy „druk”, to widzimy laser lub nawet drukarkę 3D. A jednak nawet dziś - w dobie całkowitej zmiany narzędzi pracy na stanowiskach typografa, projektanta graficznego, drukarza czy wydawcy treści „Litery” mogą służyć pomocą i inspiracją, bowiem mimo całkowitej rewolucji technologicznej w poligrafii niewiele straciły na aktualności: cechuje je nie tylko wysoki poziom merytoryczny, ale także specyficzne ujęcie, dzięki któremu pokazywany jest raczej sens i istota pracy literniczej, aniżeli jej urzeczywistnianie. Fakt ten uświadamia nam, że sednem pracy literniczej jest nie tylko rzemieślnicza biegłość w posługiwaniu się narzędziami i techniką, ale przede wszystkim pewien specyficzny, humanistyczny w swoim charakterze, sposób myślenia o literach i komunikacji za ich pomocą. Gdyby było inaczej treści z łamów „Litery”, wychodzącej w czasach druku opartego o tzw. gorący skład, byłyby dziś - w dobie druku w całości scyfryzowanego i usieciowionego - interesujące wyłącznie dla wąskiego grona historyków kultury materialnej i techniki. Sens opublikowania antologii Lit[t]era Romana, najdobitniej zawiera się w słowach Moniki Marek-Łuckiej, która pisała:

Studiowanie roczników „Litery” to piękne i wyjątkowe spotkania z mistrzami «czarnej sztuki», a także swego rodzaju podróż sentymentalna do najważniejszych momentów w historii typografii. [...] Henryk Sakwerda na pytanie, co nie wydarzyłoby się bez „Litery”, po wymienieniu listy nazwisk współczesnych typografów i projektantów, dodał: «Bez „Litery” nie byłoby w Polsce wiedzy o współczesnej europejskiej typografii, o jej twórcach, teoretykach i działaczach» ${ }^{1}$.

Uznać należy, że wiedza ta jest niezbędna i dziś, toteż tym lepiej, że koniec roku 2020 przyniósł nam możliwość powrotu do treści tego czasopisma.

1 M. Marek, Misja „Litera”, „2+3D” 2012, nr 3 (44), s. 55 (w ostatnim zdaniu cytowany jest list H. Sakwerdy do autorki). 


\section{Czasopismo. Charakterystyka formalna i rzeczowa „Litery”}

„Litera” stanowiła samoistny dodatek do miesięcznika „Poligrafika”. Jak głosił podtytuł, było to czasopisma poświęcone zagadnieniom przemysłu poligraficznego, które ukazuje się regularnie od maja 1947 r. po dziś dzień2 „Poligrafika” stanowiła organ prasowy najpierw Koła Fachowego Poligrafików, a następnie Sekcji Poligrafów Stowarzyszenia Inżynierów i Techników Mechaników Polskich zjednoczonego w Naczelnej Organizacji Technicznej. Początkowo pismo to było

skierowane do szeroko pojętej branży poligraficznej, wydawców i drukarzy. Celem «Poligrafiki» było wsparcie rynku wydawniczego po zniszczeniach wojennych, jego konsolidacja i wymiana doświadczeń, a także podniesienie poziomu zawodowego pracowników przemysły poligraficznego ${ }^{3}$.

W późniejszych dekadach, kiedy uporano się ze skutkami II wojny światowej, czasopismo to nadal stanowiło źródło fachowej informacji poligraficznej, by obecnie stać się „opiniotwórczym miesięcznikiem tworzonym z myślą o ludziach poligrafii" ${ }^{4}$, co dziś oznacza nie tylko drukarzy, wydawców, producentów maszyn, urządzeń i materiałów poligraficznych, ale także pracowników agencji reklamowych, studiów graficznych oraz producentów opakowań. Opisując profil wydawniczy „Poligrafiki”, Ewa Repucho stwierdza, że

była pierwszym powojennym czasopismem poświęconym działalności wydawniczej i pierwszym, w którym - w czasach dominującej «ekonomii niedoboru» - podkreślono znaczenie estetyki druku. Od początku starano się propagować idee pięknej książki, gazety, plakatu, druku ulotnego, zaznaczając, że projektowanie druków ma także wymiar artystyczny ${ }^{5}$.

Według niej już w pierwszym okresie trwania czasopisma (1947-1956)

bardzo często poruszanym tematem były zagadnienia dotyczące pisma. Rozważano problemy czytelności pism, prezentowano zasady składu, prawidłowego ustawienia kerningu oraz trackingu itp. Starano się uwrażliwić czytelników na sprawy estetyki druku, pokazując pracę drukarzy i wydawców w szerszym, historycznym kontekście. Przedstawiano wybrane zagadnienia z zakresu historii drukarstwa, prezentowano sylwetki znanych drukarzy i projektantów pisma ${ }^{6}$.

2 Podtytuł zmieniał się nieznacznie w 1951, 1958 i 1977 r., a w 2004 r. całkowicie z niego zrezygnowano. Czasopismo było zawieszone w latach 1949-1950, ponadto częstotliwości nie udało się utrzymać w latach 1951-1957 oraz 1982-1984.

3 E. Repucho, Estetyka zaangażowana. Rola „Poligrafiki” w podnoszeniu poziomu estetycznego polskiej produkcji wydawniczej w latach 1947-1956, „Acta Universitatis Wratislaviensis. Bibliotekoznawstwo" 2008 , nr 27, s. 78.

4 O nas, poligrafika.pl, [online] poligrafika.pl/o-nas-3/ [dostęp 26.05.2021].

5 E. Repucho, Estetyka zaangażowana..., s. 78.

6 Tamże, s. 79. 
Tak nakreślona sylwetka adresata oraz profil macierzystego czasopisma wywarły wpływ na samą „Literę”. „Litera. Dodatek «Poligrafiki» poświęcony sprawom liternictwa, czcionek i matryc drukarskich" ukazywała się w latach 1966-1974 (nry 1-57) z okazjonalnymi próbami reanimacji w roku 1975 (nr 58) i 1978 (nr 59)7. Czasopismo publikowano nieregularnie (choć usiłowano się trzymać jakiegoś rytmu ${ }^{8}$ : najpierw miesięcznego, później dwumiesięcznego, kwartalnego, a na końcu rocznego):

Tabela 1. Liczba zeszytów w poszczególnych numerach „Litery”

\begin{tabular}{|c|c|c|c|c|c|c|c|c|c|c|c|c|}
\hline Rocznik & 1 & 2 & 3 & 4 & 5 & 6 & 7 & 8 & 9 & 10 & 11 & 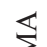 \\
\hline Rok & 1966 & 1967 & 1968 & 1969 & 1970 & 1971 & 1972 & 1973 & 1974 & 1975 & 1978 & $\bar{n}$ \\
\hline $\begin{array}{c}\text { Liczba } \\
\text { zeszytów }\end{array}$ & 8 & 10 & 10 & 9 & 5 & 5 & 4 & 4 & 2 & 1 & 1 & 59 \\
\hline
\end{tabular}

Źródło: opracowanie własne

Mimo woli redakcji dla usamodzielnienia dodatku, a nawet sygnalizowanych szans na to 9 , „Litera” nigdy nie „wybiła się na niepodległość”, choć w 1970 r. zyskała okładkę (il. 1, 2, 3) i spis treści (z uwagi na możliwość jej oddzielnego kupna; wcześniej rozpoczynał ją jedynie tytuł nagłówkowy). Ta podległość miała jednak swój sens pragmatyczny, obrazujący specyfikę pracy wydawniczej w tamtych czasach:

Wydanie «Litery» jako oddzielnego dodatku do «Poligrafiki» (do nr 57) było dobrze przemyŚlaną decyzją, dzięki której udało się uniknąć wielu kłopotów związanych z powstawaniem nowego pisma, tj. uzyskania zgody cenzury, czynników partyjnych czy przydziału papieru. «Poligrafika» to wszystko już miała, a jej renoma wielokrotnie pomagała [Romanowi] Tomaszewskiemu omijać trudności wynikające z ówczesnego systemu politycznego. Dzięki powiązaniom «Litery» $\mathrm{z}$ «Poligrafiką» władze nie ingerowały w prace redakcyjne $[\ldots]^{10}$.

7 Zeszyt 58. uczyniono pierwszym zeszytem serii „Litera. Materiały i Studia Ośrodka Badawczo-Rozwojowego Przemysłu Poligraficznego. Ośrodek Pism Drukarskich” (zob. „Litera” 1975, (R. 10), nr 1 (58), s. [3]), która miała być kontynuacją „Litery”, obejmującą „problematykę projektowania, produkcji, eksploatacji czcionek, matryc itp. nośników liternictwa poligraficznego i emitowanego", wydawaną w miarę uzyskiwania nowych informacji. Jednak zeszyt 59. nie nosi już takiego podtytułu, a w słowie od redakcji zaznacza się, że zbiory materiałów i studiów będą ukazywać się dwa razy do roku. Jak wiemy, nie doszło do tego. Seria ta raczej nie jest powiązana z serią „Materiały i Studia Ośrodka Badawczo-Rozwojowego Przemysłu Poligraficznego" (do roku 1986 ukazało się w niej co najmniej 15 numerów), bowiem nr 6. tej serii wydano jeszcze w $1974 \mathrm{r}$.

8 Por. informację na ten temat np. w: „Litera” 1970, (R. 5), nr 1 (38), s. 2.

9 „Litera” 1967, (R. 2), nr 10 (18), s. 145.

10 M. Marek, Misja..., s. 52. 
Fot. 1. Pierwsze strony „Litery”: nr 1, 17, 37, 42.

Źródło: opracowanie własne. Zdjęcie: W. Sierżęga
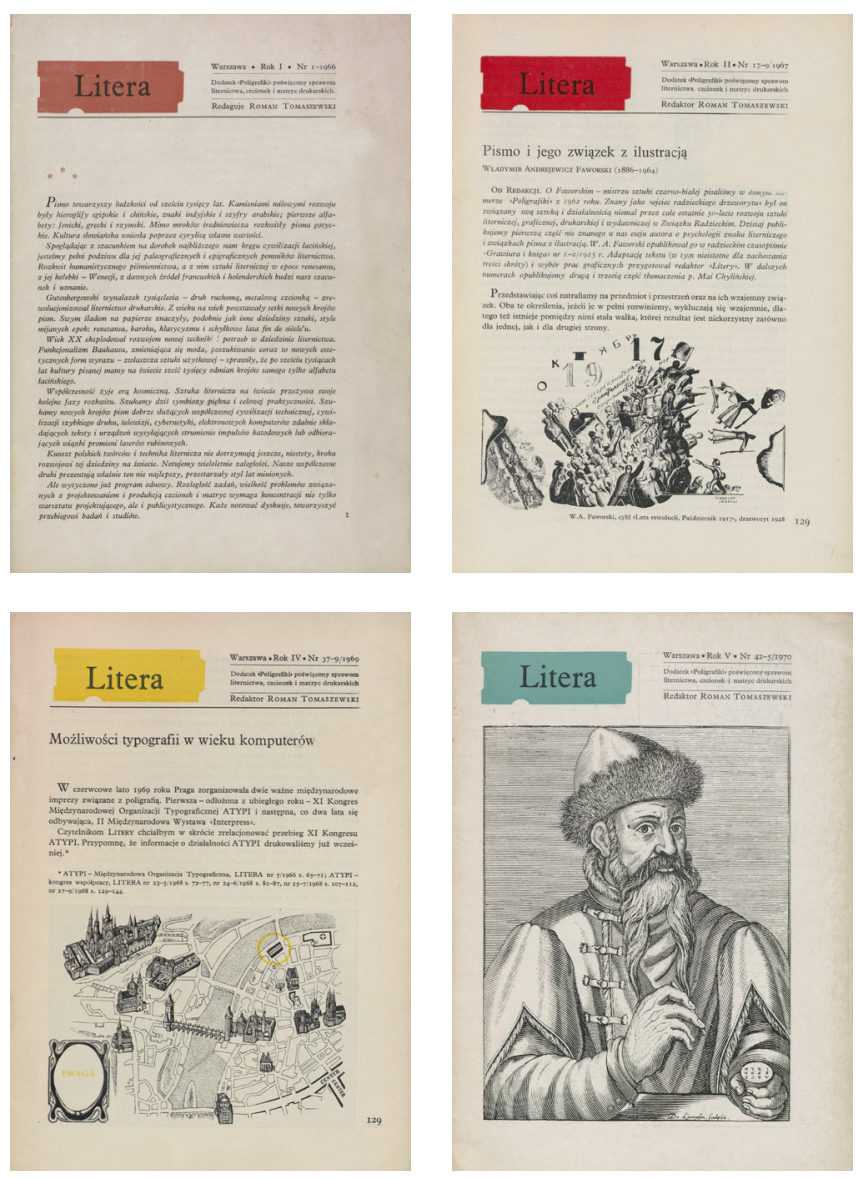

Objętość „Litery”, wydawanej przez cały okres trwania w formacie A5, systematycznie wzrastała: od początkowych 16 stron w zeszycie (w okresie 1966-1969), do nawet 64 w późniejszym okresie (zazwyczaj jednak było to od 32 do 48), co jednak w przeliczeniu na pełne roczniki i tak dawało łącznie średnio ok. 150 stron rocznie. Ostatnie dwa numery, de facto roczniki, liczyły odpowiednio 188 i 112 stron. Nakład i cenę można wskazać tylko wybiórczo. Jedynie w latach 1970-1971 informowano o możliwości prenumeraty (w cenie 50 złotych, stąd można wywnioskować, że numer był wyceniany na 10 złotych). Z kolei od roku 1972 podawano nakład: najpierw 2900 egzemplarzy, później w 1973 r. wzrósł dwa razy (do 3200, a następnie do 3250), a ostatnie dwa numery miały nakład odpowiednio 1000 i 2000 egzemplarzy. „Litera” wyróżniała się nie tylko formatem i sposobem 
dystrybucji, ale także szatą i układem graficznym: oprócz dwóch ostatnich numerów była drukowana ze składu zecerskiego, krojem Plantin, z matryc monotypowych w Domu Słowa Polskiego w Warszawie, na kredowanym papierze. Ilustracje odbijano z cynkowych klisz trawionych. Każdy numer drukowano z użyciem koloru czarnego i wyróżniającego (w każdym zeszycie był to inny kolor), a „pomimo tak różnej materii treściowej pismo nie sprawia wrażenia chaotycznego, choć różni się strukturą od typowego periody$\mathrm{ku}$ - brak w nim wydzielonych działów czy typowych ogłoszeń i reklam"11. $\mathrm{Na}$ koniec omówienia cech formalnych warto jeszcze zwrócić uwagę na winietę czasopisma: jest na niej tytuł periodyku wpisany w kształt czcionki widzianej z boku. Trudno byłoby o bardziej subtelny, a jednocześnie tak czytelny dla środowiska znak rozpoznawczy.

Zawartość „Litery” tak opisuje Andrzej Tomaszewski:

Mamy więc w «Literze» materiały o tematyce historycznej, dotyczące zarówno zmienności form pisma, jak i jego używania w przeszłości. Są teksty o projektowaniu pism drukarskich, o metodach i technikach pracy literniczej, a także o znakach i semiogramach. Często znajdujemy artykuły o czcionkach, matrycach i innych nośnikach pism, ich rodzajach, wytwarzaniu i eksploatacji oraz o technologiach składania tekstu. Mamy też teksty dotyczące typografii jako dziedziny grafiki użytkowej i szerzej - komunikacji wizualnej w ogólności. Ważną grupę artykułów stanowią te, które poruszają kwestie rozpoznawalności i czytelności pisma ${ }^{12}$.

Oprócz tego głównego zrębu pojawiały się także liczne relacje i komunikaty dotyczące międzynarodowej współpracy w tym zakresie. Bardziej szczegółowy ogląd zawartości dają układy klasyfikacji zawartości „Litery” zamieszczone w numerze 50. i 57.

Przytoczenie obu ma tę zasadność, że różna była metodyka ich tworzenia. Pierwszy układ charakteryzuje dokładniejsze obliczanie liczby artykułów, a drugi - zawiera pełne dane $\mathrm{z}$ dziewięciu lat i ma bardziej szczegółowe poddziały działów dzielonych według kryterium rzeczowego. Jednak wartości z drugiego układu nie można przyjmować za ogólną liczbę artykułów opublikowanych na łamach „Litery”, bowiem w spisie bibliograficznym niektóre artykuły opisywano wielokrotnie (jeśli tematycznie przynależały do kilku działów), a ich pozycje liczbowano ponownie; z kolei inne pozycje są pozycjami zbiorowymi łączącymi niektóre cykle w jedną pozycję (cykl ciekawostek $A$ to ciekawe, spisy bibliograficzne, indeksy, wykazy). Stąd tak mała (wydawać by się mogło - błędna) różnica sum między rokiem 1972 i 1974 (220 do 226).

11 A. Tomaszewski, Wprowadzenie do lektury, [w:] Lit(t)era Romana, oprac. M. Marek-Łucka, A. Tomaszewski, Warszawa 2020, s. 11.

12 Tamże, s. 14. 
Na potrzeby niniejszego artykułu podjęto zatem jeszcze próbę obliczenia liczby artykułów problemowych i wstępów odredakcyjnych. Pominięto komunikaty, recenzje, informacje o nowościach wydawniczych, indeksy, wykazy i spisy bibliograficzne, a artykuły podzielone na partie liczono raz, gdyż tylko taki kształt statystyczny będzie przydatny w dalszej części artykułu. Liczba ta wyniosła 151 i wynika z następujących obliczeń:

Tabela 2. Układ klasyfikacji zawartości „Litery” do roku 1972 (nry 1-50 z 59) wraz z liczbą artykułów w poszczególnych działach

\begin{tabular}{|c|c|c|}
\hline DZIAŁY I PODDZIAŁY & $\begin{array}{c}\text { LICZBA } \\
\text { ARTYKUŁÓW } \\
\text { W OBRĘBIE DZIAŁÓW } \\
\text { I PODDZIAŁÓW }\end{array}$ & $\begin{array}{c}\text { UDZIAE } \\
\text { PROCENTOWY } \\
(\%)\end{array}$ \\
\hline 1. Teoria i praktyka & $99^{13}$, w tym: & 45,0, w tym: \\
\hline 1.1. Produkcja czcionek i matryc & 37 & 16,8 \\
\hline 1.2. Projektowanie liternictwa drukarskiego & 28 & 12,7 \\
\hline $\begin{array}{l}\text { 1.3. Percepcja pism drukarskich } \\
\text { (biologiczna i bioniczna) }\end{array}$ & 10 & 4,5 \\
\hline 1.4. Zecerstwo, edytorstwo, typografia & 9 & 4,1 \\
\hline 1.5. Współpraca międzynarodowa & 15 & 6,8 \\
\hline 2. Tradycja i współczesność & 48, w tym: & 21,8, w tym: \\
\hline 2.1. Historia pism drukarskich & 13 & 5,9 \\
\hline 2.2. Sylwetki twórców & 7 & 3,2 \\
\hline 2.3. Sentencje o liternictwie & 15 & 6,8 \\
\hline 2.4. A to ciekawe... & 13 & 5,9 \\
\hline 3. Recenzje, piśmiennictwo, varia & 73, w tym: & 33,2, w tym: \\
\hline 3.1. Recenzje książek i czasopism & 31 & 14,1 \\
\hline 3.2. Bibliografia liternictwa & 8 & 3,6 \\
\hline 3.3. Przegląd patentów & 1 & 0,5 \\
\hline 3.4. Wstępy, noty redakcji, zapowiedzi & 17 & 7,7 \\
\hline 3.5. Komunikaty & 6 & 2,7 \\
\hline 3.6. Spisy autorskie i indeksy krojów pism & 10 & 4,5 \\
\hline SUMA: & 220 & 100 \\
\hline
\end{tabular}

Układ i liczba artykułów przejęte ze źródła. Wartości procentowe, zaokrąglone do pierwszego miejsca po przecinku obliczono samodzielnie Źródło: „Litera” 1972, (R. 7), nr 3 (50), s. 83

13 W oryginalnym tekście podano wartość 100, jednak suma podsum daje wartość 99. Uznając, że wartość dla całego działu była zliczona z sumy wartości poddziałów, liczbę 99 przyjęto za bardziej wiarygodną. 
Tabela 3. Układ klasyfikacji zawartości „Litery” do roku 1974 (nry 1-57 z 59) wraz z liczbą artykułów w poszczególnych działach

\begin{tabular}{|c|c|c|}
\hline DZIAŁY I PODDZIAŁY & $\begin{array}{c}\text { LICZBA } \\
\text { ARTYKUŁÓW } \\
\text { W OBRĘBIE DZIAŁÓW } \\
\text { I PODDZIAŁÓW }\end{array}$ & $\begin{array}{c}\text { UDZIAE } \\
\text { PROCENTOWY } \\
(\%)\end{array}$ \\
\hline 1. Teoria i praktyka & 119, w tym: & 52,7, w tym: \\
\hline 1.1. Projektowanie liternictwa drukarskiego & 20 & 8,8 \\
\hline $\begin{array}{l}\text { 1.2. Produkcja czcionek, matryc i innych } \\
\text { nośników literniczych }\end{array}$ & 22 & 9,7 \\
\hline 1.3. Zecerstwo. Typografia. Typowizja & 27 & 11,9 \\
\hline 1.4. Eksploatacja matryc & 5 & 2,2 \\
\hline 1.5. Analiza pism & 11 & 4,9 \\
\hline 1.6. Percepcja pism drukarskich & 15 & 6,6 \\
\hline 1.7. Współpraca międzynarodowa & 19 & 8,4 \\
\hline 2. Tradycja i współczesność & 61, w tym: & 27,0, w tym: \\
\hline 2.1. Historia pism drukarskich & 21 & 9,3 \\
\hline 2.2. Sylwetki twórców & 14 & 6,2 \\
\hline 2.3. Problemy ogólne grafiki literniczej & 17 & 7,5 \\
\hline 2.4. Liternictwo i typografia komputerowa & 8 & 3,5 \\
\hline 2.5. A to ciekawe... & 1 & 0,4 \\
\hline 3. Aparat informacyjny „Litery” & 46, w tym: & 20,4, w tym: \\
\hline 3.1. Recenzje & 33 & 14,6 \\
\hline 3.2. Bibliografie. Indeksy & 5 & 2,2 \\
\hline 3.3. Noty redakcji & 8 & 3,5 \\
\hline SUMA: & 226 & 100 \\
\hline
\end{tabular}

Układ i liczba artykułów przejęte ze źródła. Wartości procentowe, zaokrąglone do pierwszego miejsca po przecinku obliczono samodzielnie Źródło: A. Tomaszewski, Bibliografia zawartości „Litery” R. 1:1966-R. 9:1974, „Litera” 1974, (R. 9), nr 2 (57), s. 107-116

Tabela 4. Liczba artykułów problemowych i odredakcyjnych w poszczególnych numerach „Litery”

\begin{tabular}{|c|c|c|c|c|c|c|c|c|c|c|c|c|}
\hline Rocznik & 1 & 2 & 3 & 4 & 5 & 6 & 7 & 8 & 9 & 10 & 11 & \\
\hline Rok & 1966 & 1967 & 1968 & 1969 & 1970 & 1971 & 1972 & 1973 & 1974 & 1975 & 1978 & \\
\hline $\begin{array}{c}\text { Liczba } \\
\text { artykułów }\end{array}$ & 23 & 27 & 14 & 17 & 14 & 10 & 11 & 8 & 9 & 12 & 6 & 151 \\
\hline
\end{tabular}

Źródło: opracowanie własne 
Fot. 2. Okładki „Litery”: $n r$ 41, 42, 44, 45.

Źródło: opracowanie własne. Zdjęcie: W. Sierżęga
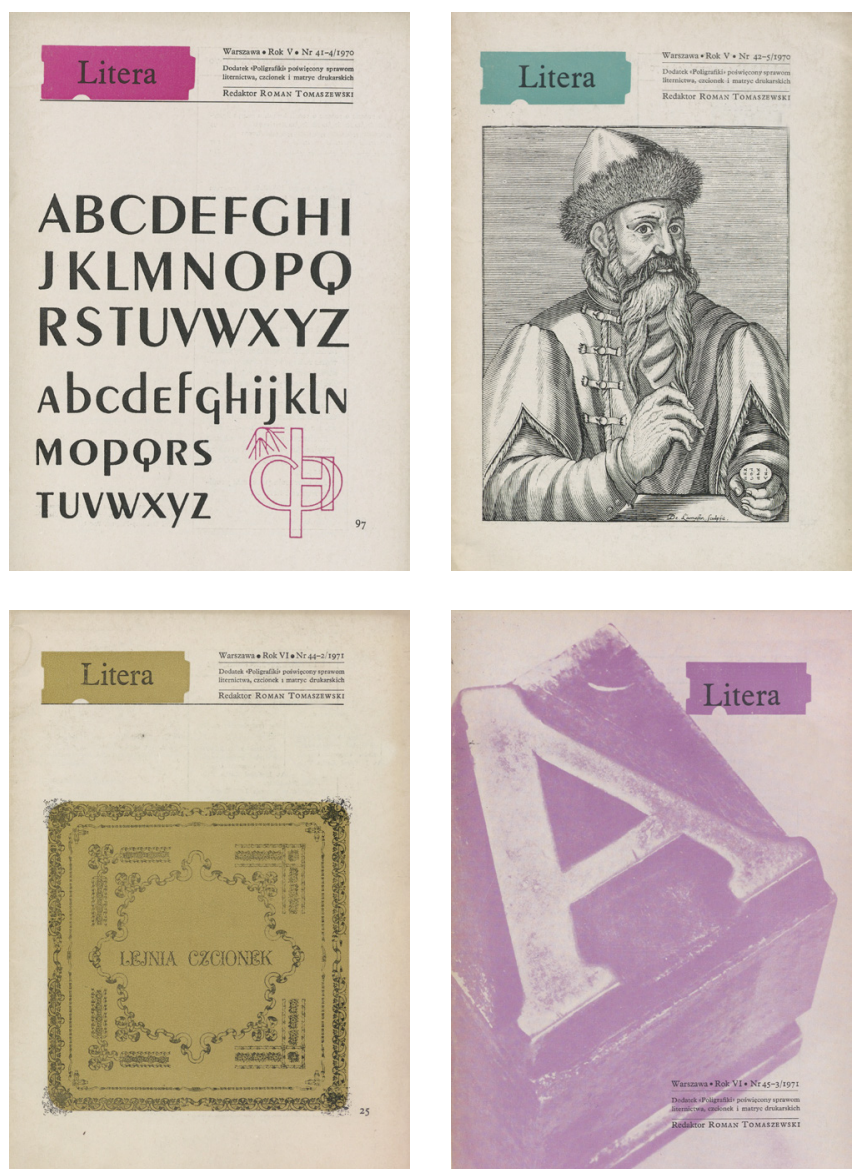

Ogółem, według słów R. Tomaszewskiego, do 1974 r. opublikowano łącznie około 250 artykułów $^{14}$, co po dodaniu zawartości z numerów z lat 1975 i 1978 daje przybliżenie około 270 wszystkich artykułów i materiałów. Niemniej zagadnienie liczby artykułów i ich charakterystyki treściowej powinno stać się przedmiotem osobnych rozważań dokonanych na podstawie spisu bibliograficznego zawartości czasopisma wykonanego w pełnej zgodności z metodyką bibliograficzną.

$\mathrm{Na}$ koniec należy zwrócić uwagę na środowisko autorów związanych z „Literą”. Wpierw warto podkreślić samą specyfikę „Litery”, która była swoistym

14 R. Tomaszewski, Stan i potrzeba rozwoju liternictwa drukarskiego, „Litera” 1974, (R. 9), nr 2 (57), s. 56. 
literniczym „oknem na Zachód” w Polsce okresu demokracji ludowej. Nawet dziś imponuje liczba zagranicznych autorów, grafików, recenzentów i thumaczy zaangażowanych w prace nad kolejnymi numerami; znajdujemy wśród nich tak duże nazwiska, o niekwestionowanej pozycji i dorobku literniczym, jak Adrian Frutiger, Albert Kapr, Tibor Szántó, Jan Tschichold czy Hermann Zapf. Nie ustępują im także polscy autorzy: Szymon Bojko, Zygfryd Gardzielewski, Andrzej Heidrich, Helena Nowak-Mroczek, Henryk Sakwerda, Władysław Semkowicz czy Leon Urbański. W ten sposób „Litera” była naturalnym kanałem przepływu dorobku typograficznego z krajów bloku kapitalistycznego do krajów bloku socjalistycznego, a - zdaniem M. Marek-Łuckiej - również w odwrotnym kierunku $^{15}$. Miało to niebagatelny wpływ także na sprawy wewnętrzne poligrafii polskiej - „Litera” nie tylko odnowiła tradycję zecerską i podniosła świadomość typograficzną w kraju, które zubożały pod wpływem skutków II wojny światowej (m.in. konfiskata matryc i czcionek) oraz gospodarki centralnie sterowanej (m.in. braki materiałowe lub ich kiepska jakość, wyśrubowane normy ilościowe, niechlujstwo, nieracjonalna oszczędność lub pośpiech), ale także miała realny wpływ na rozwój polskiej typografii na podwalinie naukowo-badawczej. Już w latach 1966-1967, za sprawą „Litery”, powołano Podkomisję ds. Czcionek i Matryc przy Zjednoczeniu Przemysłu Graficznego, która dokonała weryfikacji pism zasobu Odlewni Czcionek P.P. w Warszawie, co uporządkowało gospodarowanie zasobem literniczym w kraju i ograniczyło chaos w drukarniach ${ }^{16}$. Z kolei w $1968 \mathrm{r}$. powołano Ośrodek Pism Drukarskich ${ }^{17}$, z którym „Litera” weszła w szczególnie owocną symbiozę: artykuły niejednokrotnie powstawały na potrzeby ośrodka, $\mathrm{z}$ kolei inne artykuły okazywały się przydatne podczas prac w nim prowadzonych ${ }^{18}$. Ośrodek i „Literę” łączyła zresztą osoba R. Tomaszewskiego (o którym niżej). „Litera” mocno promowała także powstawanie nowych, rodzimych krojów pism, zachęcała do ich tworzenia i wspierała w tym celu ideę konkursów na nowe liternictwo oraz projektantów biorących udział w nich. Jeśli jednak chcemy mówić o dorobku (autorów) „Litery” i jej wpływie na polską myśl typograficzną i literniczą, to najważniejszy był (podkreślony już we wstępie) holizm, jakim cechowały się poszczególne wypowiedzi. W „Literze” przedstawiano liternictwo

15 M. Marek, Misja..., s. 55.

16 Zob. artykuły Barbary Kowalskiej: Wybór asortymentu czcionek, „Litera” 1966, nr 7, s. 102-109; Wnioski po pięciu naradach, „Litera” 1966, nr 8, s. 116-119; Weryfikacja pism, nowe zamiary, „Litera” 1967, nr 9 (17), 142-143. Sprawę tę opisuje także: M. Marek, Misja..., s. 53.

17 Powołany w Warszawie przez Zjednoczenie Przemysłu Poligraficznego jako komórka Ośrodka Badawczo-Rozwojowego Przemysłu Poligraficznego (wówczas jeszcze Centralnego Laboratorium Poligraficznego). W 1979 r. już jako Pracownia Pism Drukarskich został przeniesiony do katowickich Zakładów Mechanicznych Przemysłu Poligraficznego „Grafmasz”, gdzie jednak nie podjął już dalszej działalności. Więcej zob. A. Tomaszewski, Ośrodek Pism Drukarskich w Warszawie (1968-1979), „Acta Poligraphica” 2020, nr 15, s. 49-67.

18 M. Marek, Misja..., s. 53 (na podstawie informacji z listu A. Tomaszewskiego do autorki). 
i typografię jako fascynujące rzemiosło, łączące umiejętności manualne z predyspozycjami intelektualnymi, czerpiącymi z wielowiekowej historii komunikacji za pomocą pisma. Według Agaty Szydłowskiej i Mariana Misiaka w tej wizji

pismo miało odzwierciedlać współczesną cywilizację, jej ducha i jej właściwości. Było bezpośrednio związane z procesami myślenia - z jednej strony, i z estetyką epoki - z drugiej. Projektant pism i drukarz stawali się zatem aktorami społecznymi posiadającymi ogromną odpowiedzialność - dzięki nim procesy poznawcze mogą przebiegać bez zakłóceń. Oni też są odpowiedzialni za nadanie kształtu epoce ${ }^{19}$.

I, jak zaraz podkreślają, wobec tego nie istniała w niej prawie teraźniejszość, a świat przedstawiony dzielił się wyłącznie na zacofane, anachroniczne polskie „wczoraj”, spustoszone wojnami i gospodarką centralnie sterowaną, oraz oczekiwane ,jutro", które, dzięki rozwojowi technologicznemu (w tym rozwojowi drukarstwa), przyniesie całej ludzkości możliwości rewolucjonizujące komunikację międzyludzką w oparciu o wiedzę i edukację.

Często podkreśla się, że „Litera” była pierwszym i jedynym czasopismem specjalistycznym podejmującym tematykę liternictwa i czcionkarstwa w Polsce. Jest w tym sporo prawdy: inne polskie periodyki ${ }^{20}$ podejmowały ją marginalnie, o ile w ogóle. Także za granicą w owym czasie trudno byłoby znaleźć dokładny odpowiednik tak ukształtowanego czasopisma. Oczywiście zagadnienia pisma, litery i czcionki pojawiały się w pewnych tytułach: w jednych pomiędzy innymi zagadnieniami poligrafii, w innych jako zagadnienie główne - dla przykładu wymieńmy angielskie ${ }^{21}$, amerykańskie ${ }^{22}$, czeskie ${ }^{23}$, japoń-

19 A. Szydłowska, M. Misiak, Paneuropa, Kometa, Hel. Szkice z historii projektowania liter w Polsce, Kraków 2015, s. 111. Wyróżnienie własne.

20 W zasadzie jedynie wspomniana „Poligrafika” (Warszawa, 1947- ). Warto wspomnieć także o cyklu „Biuletynu Poligraficznego” przybliżającym w latach 1974-1979 dzieje drukarstwa w Polsce, zob. K. Socha, Z dziejów drukarstwa polskiego. Cykl artykułów z „Biuletynu Poligraficznego”, „Acta Poligraphica” 2020, nr 16, s. 43-74. Wiele lat później do tego szczupłego forum na rynku prasowym dołączyły „Acta Poligraphica” (Warszawa, 2013-), zob. R.S. Świątek, Szukającym wiedzy i prawdy, czyli naukowo o poligrafii, „Sztuka Edycji” 2013, nr 5, s. 154-156; E. Repucho, Acta Poligraphica. Czasopismo naukowe poświęcone poligrafii, 2013, R. 1, wol. 1 [recenzja], ,Roczniki Biblioteczne" 2013, nr 57, s. 178-182.

21 „The Monotype Recorder. Theory, design and practice in visual communications" (Salfords, 1902-1932, 1933-1970, 1979-1990) czy „Baseline. International typographics magazine”(London, 1979-).

22 „Journal of Typographic Research. The journal for research on the visual media of language expression” (Cleveland, 1967-1970) wraz z kontynuacją „Visible Language. The journal for research on the visual media of language expression" (Cleveland, 1971-). Można tu jeszcze wskazać „Upper and Lower Case. The international journal of typographics” (New York, 1974-1999).

23 „Typografia. Časopis pro technické a společenské zájmy knihtiskařu”" (Praha, 1888-2014). 
skie $^{24}$, niemieckie ${ }^{25}$, szwajcarskie ${ }^{26}$ czy węgierskie ${ }^{27}$. Jednak wydaje się, że tak wyraźnie misyjny i w pewnym sensie futurystyczny charakter miała wyłącznie „Litera”. Ostatecznie do dziś nie powtórzono ${ }^{28}$ krótkotrwałego sukcesu „Litery", jakim było samodzielne czasopismo wyspecjalizowane w zagadnieniach „liternictwa, czcionek i matryc drukarskich” i tego rodzaju treści muszą szukać łamów w bliskich tematycznie czasopismach z zakresu typografii, projektowania graficznego, designu i komunikacji. Była więc „Litera” ewenementem ${ }^{29}$ :

24 „日本レタリング年鑑” [Nihon retaringu nenkan = Japan Lettering \& Typography Annual] (Tōkyō, 1969-1972) wraz z kontynuacją „,日本タイポグラフィ年鑑” [Nihon taipogurafi nenkan = Japan Typography Annual] (Tōkyō, 1974-1989) i „日本タイポグラフィ年鑑” [Nihon taipogurafi nenkan = Applied Typography] (Tōkyō, 1991-). Wbrew nazwie do 1991 r. był to dwurocznik. W roku 1991 nie zmienił się tytuł główny, a jedynie równoległy. Można spotkać także oboczności tłumaczenia: Annual/ Almanac/Yearbook. Z powodu ograniczonego przepływu informacji z tego kręgu kulturowego podaję jeszcze źródło dalszych informacji na temat tego periodyku: 日本のロゴ・マーク50年:日本タイポグラフィ 年鑑40冊よりベスト作品1000点のアーカイブ, 日本タイポグラフイ協会 編, 東京 2020 (Nihon no rogo māku 50-nen. Nihon taipogurafi nenkan 40-satsu yori besuto sakuhin 100-ten no ākaibu, Nihon Taipogurafi Kyōkai, Tōkyō $2020=50$ years of Japanese logotypes and symbol marks. An archive of 1000 best works from 40 volumes of Applied Typography, comp. by the Japan Typography Association, Tōkyō 2020).

25 Przede wszystkim „Die Zeitgemässe Schrift. Studienhefte für Schrift und Formgestaltung” (Berlin, Lipsk, 1927-1943), „Linotype-Post. Hausmitteilungen der Linotype GmbH” (Berlin, 19281941, 1950-1958, 1958-1975, 1977), ale także „Papier und Druck. Fachzeitschrift für Typographie, Polygrafische Technik und Papierverarbeitung” (Leipzig, 1952-1991) czy „Gutenberg-Jahrbuch” (Wiesbaden, Mainz, 1926-).

26 „Typographische Monatsblätter. Typo, Graphik, Photo, Druck” i jego późniejsze kontynuacje o zmiennych tytułach i miejscach wydania (1933-2014).

27 „Papír és Nyomdatechnika. A papirosiparok és a grafikai iparok dolgozóinak szaklapja [...] (Budapest, 1948-1956; szczególnie dodatek „Magyar Tipográfia” ukazujący się w latach 1954-1956) wraz z kontynuacją „Magyar Grafika. A Papír- és Nyomdaipari Müszaki Egyesület [...]” (Budapest, 1957-).

28 Efemerycznie pojawiło się na początku lat 90. XX w. jeszcze czasopismo „Pro Typo. Kwartalnik Sekcji Polskiej Międzynarodowego Stowarzyszenia Typograficznego ATYPI”, które - wedle słów odredakcyjnych w pierwszym numerze - nawiązywało świadomie do idei i misji „Litery” i miało być niejako jej kontynuacją. Niestety, w latach 1991-1992 ukazało się jedynie pięć numerów. Redaktorem naczelnym był A. Tomaszewski, ale „mecenasem, promotorem i redakcyjnym partnerem przedsięwzięcia był [znów! - JMŁ] R. Tomaszewski” - więcej zob.: A. Tomaszewski, „Pro Typo”zapomniane czasopismo zawodowe, „Acta Poligraphica” 2019, nr 14, s. 41.

29 Nie pierwszy raz zresztą opisywanym w literaturze. „Literze”, oprócz artykułu M. Marek-Łuckiej (M. Marek, Misja..., s. 50-55), poświęcono także dwie dysertacje: magisterską (E. Kowalik, ,Litera” (1966-1974). Dodatek do „Poligrafiki”, [praca magisterska napisana pod kierunkiem doc. dr hab. H. Tadeusiewicz w Katedrze Bibliotekoznawstwa i Informacji Naukowej Uniwersytetu Łódzkiego], 1984) i licencjacką (A. Luberda, Dyskurs teoretyczny wokół krojów pisma na łamach „Litery. Dodatku do »Poligrafiki« dotyczacego spraw liternictwa, czcionek i matryc drukarskich", [praca licencjacka napisana pod kierunkiem dr M. Komorowskiej w Katedrze Edytorstwa i Nauk Pomocniczych Uniwersytetu Jagiellońskiego], 2016). Na podstawie tej ostatniej przygotowano jeszcze artykuł: A. Luberda, „Litera” Romana Tomaszewskiego. Pierwsze pismo typograficzne w Polsce zarys historii i przybliżenie tematyki, „Rubryka” 2017, nr 3, s. 52-66, [online] issuu.com/kneuj/ docs/rubryka_3 [dostęp 28.05.2021]. Treści z „Litery” posłużyły także za jedno ze źródeł do opisu rozwoju projektowania liter w Polsce w: A. Szydłowska, M. Misiak, Paneuropa, Kometa, Hel..., s. 92-115. Przy okazji poruszonych zostało wiele spraw związanych z samym czasopismem oraz jego wpływem na polską typografię i liternictwo. 
„W ówczesnym świecie zakazów, nakazów, ograniczonych przydziałów papieru i innych przejawów biurokracji "przodującego ustroju socjalistycznego»" ${ }^{30}$ czasopismo wyróżniało się nie tylko nowoczesnymi artykułami, podążającymi za najnowszymi trendami w swojej dziedzinie, ujętymi w atrakcyjną szatę graficzną, ale przede wszystkim międzynarodowym gronem autorów z najwyższej półki. Ich pozyskanie - czy to do stworzenia treści, czy też nadania jej formy nie byłoby możliwe, gdyby nie spiritus movens całego przedsięwzięcia.

Fot. 3. Okładki „Litery”: nr 53, 55, 58, 59.

Źródło: opracowanie własne. Zdjęcie: W. Sierżęga
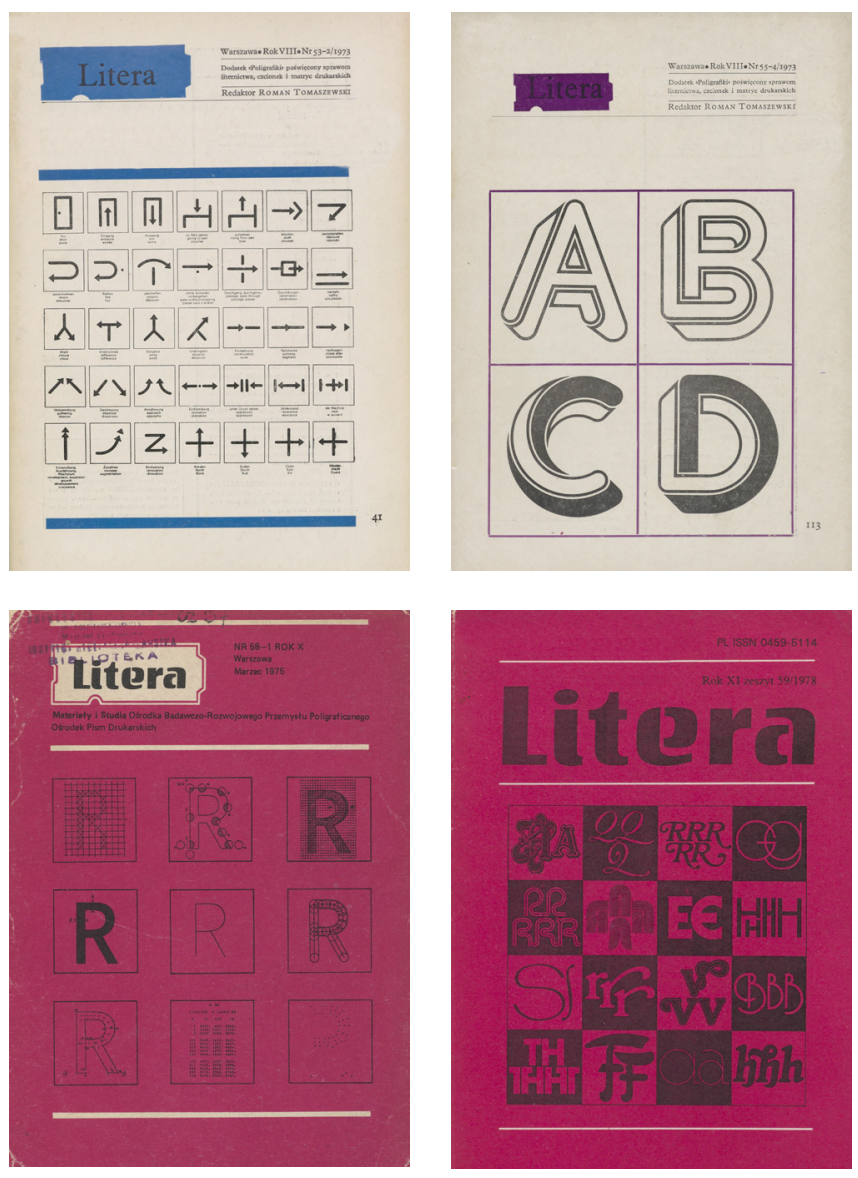

30 A. Tomaszewski, Wprowadzenie..., s. 14. 


\section{Ludzie. Redaktor „Litery” i redaktorzy antologii „Litery”}

Redaktorem „Litery” przez cały okres jej trwania był R. Tomaszewski (urodzony 21 II 1921 r. w Poznaniu, zmarły 30 XII 1992 r. w Warszawie). Wybitna postać, ogromnie zasłużona dla polskiej typografii i poligrafii, wykładowca projektowania liternictwa drukarskiego (inspirator dwóch pierwszych dyplomów magisterskich z liternictwa drukarskiego w Polsce ${ }^{31}$ ), członek Association Typographique Internationale (ATypI), Polskiego Towarzystwa Wydawców Książki, towarzystw bibliofilów w Toruniu i Warszawie, laureat lipskiej Nagrody Gutenberga (1972), prywatnie bibliofil. „Znany był głównie jako specjalista i organizator projektowania liternictwa drukarskiego oraz inicjator stosowania w polskim ruchu wydawniczym automatycznej techniki wydawniczej" ${ }^{32}$. Bibliografia jego prac (artykułów, wywiadów, polemik, audycji radiowych, recenzji, tłumaczeń, sprawozdań i ekspertyz) liczy 438 pozycji, w tym m.in. ważne $\mathrm{z}$ dokumentacyjnego punktu widzenia prace porządkujące bazę dydaktyczną, pojęciową i faktograficzną ${ }^{33}$, czym wyraźnie wsparł rozwój polskiej bibliologii.

Swoją pracą, znajomością rzeczy, ofiarnością i ofensywną postawą budował przez lata osobisty autorytet. [...] Jego opinie prezentowane w artykułach nie były jednostronne i subiektywne. Powstawały w toku wielogodzinnych rozmów i seminariów w gronie innych specjalistów i fachowców ${ }^{34}$.

Pracowity i energiczny do ostatniego dnia, nie tylko teoretyk, ale przede wszystkim praktyk swojego fachu. Nie sposób w tym miejscu zarysować choćby pobieżnej biografii i dokonań R. Tomaszewskiego ${ }^{35}$ - szczęśliwie zwięzłe

31 Krój Helikon autorstwa Heleny Nowak i krój Kurier autorstwa Małgorzaty Budyty. Stanowiły podstawę obron na akademii Sztuk Pięknych w Warszawie (pracownia prof. Józefa Mroszczaka). Zob. A. Sobocińska, A. Tomaszewski, Bibliografia prac poligrafa, wydawcy i bibliofila Romana Tomaszewskiego (1921-1992) za lata 1948-1994, [w:] Studia o ksiażce dawnej i wspótczesnej, pod red. I. Imańskiej, J. Tondela, Toruń 2006, s. 39.

32 Tamże, s. 37.

33 [R. Tomaszewski], Program szkolenia redaktorów. Studium techniczno-wydawnicze. Cz. 1, Warszawa [1956].

R. Tomaszewski, Klasyfikacja pism drukarskich ART, [w:] Z badań nad dawna książa. Studia ofiarowane profesor Alodii Kaweckiej-Gryczowej w 85-lecie urodzin. T. 2, [kom. red. P. Buchwald-Pelcowa i in.], Warszawa 1993, s. 663-676.

R. Tomaszewski, Materiaty do bibliografii na temat Czytelności pism drukarskich, Warszawa 1973.

34 A. Sobocińska, A. Tomaszewski, Bibliografia prac..., s. 40.

35 W tym miejscu zachęcam czytelników do przestudiowania istniejących już opracowań: A. Tomaszewski, Tomaszewski Roman, [w:] Słownik pracowników książki polskiej. Suplement 2, pod red. H. Tadeusiewicz z udziałem B. Karkowskiego, Warszawa 2000, s. 163; A. Sobocińska, A. Tomaszewski, Bibliografia prac..., s. 37-40; A. Chamera-Nowak, Roman i Andrzej Tomaszewscy w niewoli ksiażek, [w:] W poszukiwaniu odpowiedniej formy. Rola wydawcy, typografa, artysty i technologii w pracy nad ksiązka, pod red. M. Komzy przy współudz. E. Jabłońskiej-Stefanowicz, E. Repucho, Wrocław 2012, s. 217-231. We wszystkich tych pracach dalsza bibliografia. 
jej przypomnienie zawiera sama antologia ${ }^{36}$. Niemniej R. Tomaszewski z pewnością zasłużył na monografię poświęconą jego życiu, twórczości i wkładu w polską i światową typografię ${ }^{37}$. To kolejny dezyderat stawiany w tym artykule.

Fot. 4. Okładka Lit[t]era Romana

Źródło: opracowanie własne. Zdjęcie: W. Sierżęga

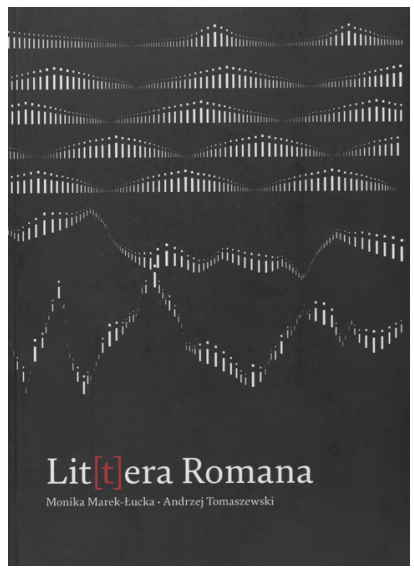

Swoją pasję R. Tomaszewski przekazał synowi, Andrzejowi Tomaszewskiemu (urodzonemu 11 VI 1948 we Wrocławiu), który jednocześnie jest współredaktorem antologii i kontynuatorem myśli przyświecających całe życie ojcu szczególnie jako redaktor „Pro Typo" i zastępca redaktora „Acta Poligraphica” oraz autor kilku wybitnie ważnych źródeł informacji z zakresu poligrafii ${ }^{38}$; jest również, jak ojciec, typografem z doświadczeniem - opracował graficznie około 300 książek i czasopism. A. Tomaszewski z pasją i zaangażowaniem upamiętnia dzieło ojca, ale także twórczo je rozwija. Był naturalnym kandydatem na redaktora antologii „Litery” nie tylko z uwagi na pokrewieństwo

O tym, jak istotną dla środowiska postacią był R. Tomaszewski świadczy fakt, że nawet po śmierci był przypominany na łamach prasy fachowej, zob. np.: IZ [Iwona Zdrojewska], Edytor, typograf, bibliofil, erudyta, „Poligrafika” 2003, nr 3, s. 76-77. G. Sowula, Roman, „Notes Wydawniczy” 2002, nr 12, s. 68-69.

36 A. Tomaszewski, Wprowadzenie..., s. 9-10.

37 Wzmiankowana jest praca magisterska na temat R. Tomaszewskiego przygotowywana przez Adriannę Sobocińską, zob.: A. Sobocińska, A. Tomaszewski, Bibliografia prac..., s. 41. Ośrodek, promotor i dalsze losy tej pracy są mi nieznane.

38 A. Tomaszewski, Giserzy czcionek w Polsce. Poczet odlewaczy czcionek działajacych $w$ dawnej Polsce oraz polskich za granica, Warszawa 2009.

A. Tomaszewski, Pismo drukarskie, pod red. H. Janowskiego, Wrocław 1989.

A. Tomaszewski, Leksykon pism drukarskich, Warszawa 1996.

A. Tomaszewski, Architektura ksiązki dla wydawców, redaktorów, poligrafów, grafików, autorów, księgoznawców i bibliofilów, Warszawa 2018.

Współautor: Angielsko-polski leksykon terminów poligraficznych, pod red. L. Markowskiego, Warszawa 2013. 
i zainteresowanie tematem, ale także z tego powodu, że był autorem kilku tekstów opublikowanych na łamach „Litery”, a zatem jej współtwórcą; w ostatnim numerze (59) wskazany był ponadto jako sekretarz redakcji.

Drugą redaktorką antologii i jednocześnie osobą odpowiedzialną za jej opracowanie graficzne jest Monika Marek-Łucka. Jako kaligrafka, graficzka i projektantka informacji wizualnej, z dyplomami Akademii Sztuk Pięknych we Wrocławiu na Wydziale Grafiki oraz filozofii na Uniwersytecie Warszawskim, zajmująca się liternictwem nie tylko jako rzemiosłem, ale także jako nośnikiem znaczeń z punktu widzenia estetyki, semiotyki i teorii obrazu ${ }^{39}$, również miała pełne kompetencje by podjąć się tego zadania. To dzięki jej zainteresowaniu i zaangażowaniu w ogóle powstała ta książka: po opublikowaniu cytowanego tu już artykułu i udziału w Lubelskim Spotkaniu Typograficznym TypoLub (oba wydarzenia miały miejsce w 2012 r.) M. Marek-Łuckiej

zaświtała myśl o wydaniu antologii tekstów wybranych z «Litery». Podzieliła się ze mną [A. Tomaszewskim - JMŁ] swoim pomysłem i poprosiła o przygotowanie redakcyjne staromodnych już nieco artykułów. Ja zaś, jako syn założyciela i redaktora «Litery», widząc konkretny zamiar i ochotę, przyjąłem propozycję młodej graficzki z wdzięcznością za pamięć o ojcu i jego pracy ${ }^{40}$.

Natomiast wyłącznie uporowi obu redaktorów zawdzięczamy możliwość ponownego obcowania z tekstami „Litery” - mimo że prace nad książką trwały łącznie osiem lat, z czego same zabiegi o wydanie, redakcja i korekty trwały aż trzy lata, to trzech kolejnych wydawców rezygnowało z jej wydania. Pierwszy zdecydowanie odmówił, drugi nie podołał skomplikowanym sprawom prawnoautorskim (część autorów artykułów już nie żyje) i po początkowym zaangażowaniu ostatecznie się wycofał, trzeci z kolei wydatnie pomógł przy redagowaniu tekstów, natomiast sprawę samego wydania odwlekał zbyt dłu$\mathrm{go}^{41}$. Habent sua fata litterae. Ostatecznie sprawę udało się sfinalizować dzięki profesor Ewie Sataleckiej, dziekan Wydziału Sztuki Nowych Mediów Polsko-Japońskiej Akademii Technik Komputerowych (wykładowczynią na tej samej uczelni jest M. Marek-Łucka), która pozyskała grant z programu „Future Text” finansowanego przez Narodową Agencję Wymiany Akademickiej. W ten oto sposób w połowie grudnia 2020 r. druk nakładu antologii szczęśliwie został ukończony i 30 XII 2020 r. odbyło się (w trybie zdalnym) spotkanie autorskie poświęcone książce. O jego atrakcyjności (a tym samym o nieprzemijającym zainteresowaniu treściami z „Litery”) świadczy fakt, że zgromadziło ponad

39 Monika Marek-Lucka, [online] snm.pja.edu.pl; snm.pja.edu.pl/project/monika-marek-luc$\mathrm{ka} /$ [dostęp 7.06.2021].

40 A. Tomaszewski, Wprowadzenie..., s. 9.

41 Z listu elektronicznego od A. Tomaszewskiego z dnia 9 VI 2021 r. (w archiwum autora). 
70 zainteresowanych uczestników i trwało ponad 2,5 godziny ${ }^{42}$. Oprócz redaktorów (wskazanych w preliminariach jako „opracowujący”) nad książką pracowało łącznie 12 osób, w tym Filip Modrzejewski, Katarzyna Wójcik, Martyn Kramek (jako „redaktorzy”), Robert Chwałowski, Szymon Łucki, Ewa Tomaszewska (jako ,pomoc w przygotowaniu materiału tekstowego”). Recenzje wydawnicze wykonały E. Repucho z Uniwersytetu Wrocławskiego i.Klaudia Socha z Uniwersytetu Jagiellońskiego.

\section{Antologia. Lit[t]era Romana}

Antologię ${ }^{43}$ zatytułowano Lit[t]era Romana. Antologia tekstów z czasopisma „Litera” 1966-1978. Tytuł główny to swego rodzaju gra słowna z czytelnikiem: jednocześnie oznacza on pismo rzymskie, będące podwaliną wszystkich późniejszych form pisma łacińskiego, ale tłumaczony dosłownie (stąd nawias w tytule ${ }^{44}$ ) może być rozumiany jako ,(czasopismo) «Litera» Romana (Tomaszewskiego)". Jest to więc tytuł metaforyczny, a funkcję informacyjną pełni dodatek do tytułu. Razem tytularia prawidłowo oddają zakres pracy. Adresat nie został wskazany bezpośrednio w tekście - jego domniemaną sylwetkę odnajdujemy dopiero w umieszczonej na okładce wypowiedzi Krzysztofa Tyczkowskiego, typografa, projektanta graficznego, profesora w Akademii Sztuk Pięknych im. Władysława Strzemińskiego w Łodzi: „Antologia tekstów z «Litery» z pewnością przyda się dzisiejszym typografom, grafikom projektantom, wydawcom i drukarzom, którzy będą mogli docenić wartość informacji z czasopisma [...]"45. Uzupełnia ją wypowiedź Adama Twardocha, poczyniona na wyżej wspomnianym spotkaniu autorskim, która wskazuje z kolei przeznaczenie czytelnicze:

[...] jeśli chodzi o projektowanie liter, to poza kwestiami technicznymi niewiele się zmieniło, a tu mamy do czynienia z uwagami autorskimi dotyczącymi projektowania krojów „z pierwszej ręki”. Książkę można więc traktować jako podręcznik i zbiór esejów, które się w zasadzie nie zestarzały ${ }^{46}$.

42 I. Zdrojewska, Od Alphabetum Romanum do pism komputerowych. „Lit(t)era Romana”, „Poligrafika” 2021 (R. 73), nr 1, s. 61.

43 Opis bibliograficzny na II stopniu szczegółowości: Lit(t)era Romana : antologia tekstów z czasopisma ,Litera” 1966-1978 / opracowali: Monika Marek-Łucka, Andrzej Tomaszewski. Warszawa : Wydawnictwo PJATK, 2020. - 404, [4] strony : ilustracje ; $24 \mathrm{~cm}$.

44 Niezręczny z bibliograficznego punktu widzenia, bowiem graficznie został on zrealizowany w antologii poprzez nawiasy kwadratowe, które to w metodyce bibliograficznej są zarezerwowane dla uzupełnień pochodzących spoza dokumentu i/lub od bibliografa. Stąd w opisie bibliograficznym tytuł ten zapisywany jest jako Lit(t)era Romana.

45 Lit(t)era Romana. Antologia tekstów z czasopisma „Litera” 1966-1978, oprac. M. Marek-Łucka, A. Tomaszewski, Warszawa 2020, s. IV okładki.

46 I. Zdrojewska, Od Alphabetum Romanum..., s. 61. 
Ogólnie, antologię, na którą składają się artykuły będące bogatym źródłem wiedzy o typografii i liternictwie, projektowaniu i czytelności pism oraz percepcji informacji poprzez pismo, można polecić każdemu zainteresowanemu tą tematyką lub poszukującemu inspiracji do własnych rozważań i badań. Obecność materiałów odredakcyjnych i sprawozdawczych z kolei może wnieść pewien wkład w badania o nachyleniu historycznym i socjologicznym, obrazując tamtą epokę oraz technologię.

$\mathrm{Na}$ tekst główny antologii składa się 47 wznowień artykułów. Stanowi to $\sim 31 \%$ z sumy ww. 151 artykułów problemowych i odredakcyjnych. Antologia przynosi zatem $1 / 3$ zasadniczej objętości całego czasopisma. Dobór artykułów opisano następująco:

Wybór tekstów, jakiego dokonaliśmy do niniejszej publikacji, oddaje chyba ducha czasopisma, chociaż w zbiorze nie znalazły się krótkie informacje, wzmianki, komunikaty, które w «Literze» zajmują sporo miejsca. [...] Wybraliśmy artykuły, które zawierają do dziś aktualną wiedzę praktyczną i teoretyczną ${ }^{[4]}$ oraz takie, które pokazują ówczesne uwarunkowania technologiczne i sposób myślenia o przyszłości ${ }^{[48]}$ charakterystyczny dla szóstej i siódmej dekady XX wieku ${ }^{49}$.

Dopisane w przypisach przykładowe artykuły wskazują, że zamierzenie to udało się zrealizować i w mojej ocenie znalazły się tu wszystkie ważniejsze artykuły publikowane na łamach „Litery”. Brakuje może jedynie artykułu(ów) $\mathrm{R}$. Tomaszewskiego na temat typometrii pism drukarskich ${ }^{50}$ - artykuł ten zwięźle opisuje problem od czasów najdawniejszych po wprowadzenie Międzynarodowego Układu Jednostek Miar, a w polskiej literaturze przedmiotu ten problem

47 Przykładowo: Metodyka projektowania pism drukarskich oraz Anatomia liter tacińskich A. Kapra; Częstość występowania liter w języku polskim oraz O czytaniu i czytelności znaków drukarskich B. Kowalskiej; Problemy projektowania pism dziełowych H. Zapfa; Rozpoznawalność i czytelność pisma w gazecie oraz Stan i potrzeba rozwoju liternictwa drukarskiego R. Tomaszewskiego czy Kryteria oceny czytelności pisma Dirka Wendta.

48 Przykładowo: Droga otwarta do pisma uniwersalnego Jeana Daniela Julliena; Wideograf a ksiażka. Rewolucja czy ewolucja przekazu słowa oraz Koniec klasycznej typografii a nadchodzacy czas liczb progresywnych H. Zapfa; Awangardowe publikacje informacyjne Jana Rapackiego czy Formy literowe $w$ fototypografii A. Frutigera.

49 A. Tomaszewski, Wprowadzenie..., s. 14.

50 Chodzi o dwa, komplementarne względem siebie i połączone wspólną narracją artykuły: R. Tomaszewski, Typometria pism drukarskich, „Litera” 1967, (R. 2), nr 3 (11), s. 41-44; R. Tomaszewski, Typograficzny system calowy i uniwersalny, „Litera” 1967, (R. 2), $\mathrm{nr} 4$ (12), s. 59-61. Wiadomości z tego artykułu zostały wydatnie poszerzone w ciągu artykułów: R. Tomaszewski, $T y$ pometria, cz. 1-8, „Poligrafika” 1980, (R. 32), nr 4, s. 104-106, nr 5, s. 135-136, nr 7, s. 191-192; 1981, (R. 33), nr 3, s. 69-70, nr 5-6, s. 134-135, nr 7-8, s. 166-167; 1982, (R. 34), nr 1, s. 31-33, nr 3, s. 100-101. Ciąg ten wygląda na niedokończony (przynajmniej na to wskazuje adnotacja „cdn.” po 8. części), choć być może ciąg ten miał formułę otwartą. Korzysta się z tego artykułu trudno: z powodu dostępności archiwalnych numerów „Poligrafiki”, ale przede wszystkim - rozdrobnienia artykułu pomiędzy kolejnymi częściami. 
wciąż jest niedostatecznie opisany ${ }^{51}$, stąd jego przypomnienie poprzez antologię „Litery” mogłoby przyczynić się do jego popularyzacji.

Układ artykułów jest chronologiczny wstępujący i jest to o tyle zasadne, że lektura antologii „od deski do deski” zapewni ogląd rozwoju polskiej myśli o liternictwie i wpływ badaczy zagranicznych na nią. Jeśli jednak praca ta miałaby służyć jako podręcznik czy kompendium (a cytowano tu już takie głosy), właściwszym byłby jakiś układ rzeczowy, wyróżniający kilka głównych grup zagadnień. Pomocą mogła służyć wzmiankowana tu już bibliografia zawartości „Litery”:

Tabela 5. Frekwencja artykułów wybranych do antologii „Lit[t]era Romana” względem ich przynależności do działów układu bibliograficznego zawartości czasopisma „Litera”

\begin{tabular}{|c|c|}
\hline TEMATYKA LUB FORMA ARTYKUŁU & LICZBA ARTYKUŁÓW \\
\hline Projektowanie liternictwa drukarskiego & 10 \\
\hline Zecerstwo. Typografia. Typowizja & 9 \\
\hline Problemy ogólne grafiki literniczej & 7 \\
\hline Analiza pism & 5 \\
\hline Percepcja pism drukarskich & 5 \\
\hline Historia pism drukarskich & 3 \\
\hline Współpraca międzynarodowa & 2 \\
\hline Noty redakcji & 2 \\
\hline Recenzje & 1 \\
\hline
\end{tabular}

W przypadku artykułów przypisanych do kilku działów arbitralnie dokonywano wyboru jego jednokrotnej przynależności do działu. Pominięto trzy artykuły,

które opublikowano poza zasięgiem chronologicznym bibliografii (w roku 1978) Źródło: opracowanie własne na podstawie: A. Tomaszewski, Bibliografia zawartości „Litery” R. 1:1966 - R. 9:1974, „Litera” 1974, nr 2 (57), s. 107-116

Na jej podstawie widać, że można byłoby zgrupować artykuły wokół takich zagadnień jak: projektowanie liternictwa; zecerstwo i typografia; problemy ogólne liternictwa; pismo drukarskie: analiza, percepcja, historia.

Poza tekstem głównym publikację wyposażono w materiały wprowadzające (cytowane tu obszernie „Wprowadzenie do lektury”, zwięźle przedstawiające postać R. Tomaszewskiego, fenomen „Litery” oraz losy wydawnicze samej antologii) oraz uzupełniające (antologia jest obficie ilustrowana - zawiera zarówno materiał ilustracyjny do artykułów, jak również reprodukcje pierwszych stron niektórych zeszytów; z kolei fotografie R. Tomaszewskiego otwierają

51 Poza artykułami z poprzedniego przypisu oraz informacjami zamieszczonymi w podręcznikach drukarskich i poligraficznych, można wskazać jedynie na pracę: K. Szymański, Systemy miar w typometrii, „Przegląd Papierniczy” 2012, (R. 68), nr 4, s. 211-214, 216. Niestety nie podano w niej żadnych źródeł, na których ją oparto. 
i zamykają publikację). Natomiast na materiały informacyjno-pomocnicze składają się spis treści, cyfrowa i żywa pagina, lokalizacja bibliograficzna oryginału artykułu (numer i rok wydania zeszytu „Litery” podany przy każdym tytule artykułu), biogramy autorów tekstów (także tych, których żaden tekst nie znalazł się w antologii), wykaz pozostałych współtwórców (graficy, recenzenci, tłumacze) oraz indeks osób. Obecność tych materiałów bardzo korzystnie wpływa na odbiór i korzystanie z pracy. W tym miejscu można byłoby zasugerować jeszcze, aby i pozostali współtwórcy otrzymali biogramy, a nie tylko ujęcie w wykazie. Z kolei z dokumentacyjnego punktu widzenia ogromną wyręką byłoby zamieszczenie także zrewidowanej i pełnej bibliografii zawartości „Litery” (postulowaną już wyżej) oraz scalonego indeksu krojów pism drukarskich oraz bibliografii liternictwa, których kolejne części pojawiały się na łamach „Litery”. Jednakże przygarść tych sugestii jest jedynie fakultatywnym dezyderatem, którego spełnienie musiałoby wydłużyć przecież i tak już ogromnie długi czas pracy nad publikacją. $Z$ pewnością jednak można pomyśleć o opracowaniu tego typu materiałów w osobnym wydawnictwie - byłoby to ze wszech miar pożyteczne.

Na koniec omówienia struktury i zawartości pracy należy podkreślić, że publikację opracowano niezwykle starannie, a polegało to na

[...] pewnym dostrojeniu ich [tekstów - JMŁ] dla współczesnego czytelnika, głównie poprzez skrócenie niektórych, dzisiaj nieistotnych wątków. Interwencja w teksty nie jest zbyt drobiazgowa, bo też edytorsko «Litera» daleka była od pedantyczności. Nastąpiła jednak weryfikacja pisowni nazwisk i nazw oraz, wyjątkowo, uwspółcześnienie pewnych terminów $\mathrm{z}$ zachowaniem odniesień do dawnych realiów ${ }^{52}$

oraz

[...] selekcji ilustracji z „Litery”, uwzględniającej zarówno ich wartość merytoryczną, jak i przydatność do reprodukcji ${ }^{53}$.

Nie są to więc wierne przedruki lecz teksty poddane gruntownej redakcji (il. 5, 6). Zmiany nie ograniczały się do kosmetycznych poprawek lub usunięcia oczywistych błędów. Niektóre zdania przeredagowano, dopisano lub ujęto. Całkowicie zrezygnowano z bibliografii załącznikowych, nie włączono także wszystkich ilustracji towarzyszących tekstom. Oprócz tego artykuły podzielone na części scalono $w$ jeden. $Z$ jednej strony tak znaczna ingerencja to dobra decyzja - publikacja zyskała na zwięzłości i ,podręcznikowości”. Z drugiej - czytając teksty $\mathrm{w}$ formie podanej $\mathrm{w}$ antologii nie mamy do czynienia $\mathrm{z}$ ich przedrukami, co w rzadkich sytuacjach może powodować konieczność sięgnięcia do oryginału. Jest to jednak kwestia, z którą boryka się każdy redaktor chcący na nowo

52 A. Tomaszewski, Wprowadzenie..., s. 14.

53 Tamże. 
udostępnić teksty już kiedyś opublikowane. Książkę formalnie zamyka adnotacja o liczbie ósemek drukarskich (51). Skonfrontowana z faktem, że 51 jest liczbą atomową antymonu - pierwiastka niezbędnego w czcionkowym stopie odlewniczym - stanowi kolejny element podnoszący wydawniczy smak całej publikacji.

Forma pracy także nie pozostawia czegokolwiek do życzenia. Wydana na papierze kredowanym w formacie obciętego B5 $(170 \times 236 \mathrm{~mm}) \mathrm{z}$ oprawą klejoną wykonaną z czarnego powlekanego papieru sprawia wrażenie solidnej, ale także eleganckiej. Mają na to wpływ zastosowane rozwiązania graficzne: publikację wydrukowano w kolorze czarnym z kolorem czerwonym jako kolorem wyróżniającym (zastosowanym na grzbiecie książki, w tytule i szmuctytule, żywej i cyfrowej paginie oraz lokalizacji bibliograficznej oryginału artykułu, podpisach do ilustracji oraz liniach nielicznych tabel). Ilustracje także są w skali szarości. Do składu użyto kroju FS Brabo, dzięki uprzejmości Adama Twardocha i firmy FontSmith. I w tych kwestiach, jako czytelnik antologii, przeżyłem największy zawód. Otóż, przyzwyczajony do dyskretnej barwności „Litery”, widocznej dopiero w komplecie danego rocznika, oraz - w jakiś sposób „radosnej” choć oczywiście całkowicie klasycznej - anatomii kroju Plantin, widzę czarno-czerwono-białą estetykę antologii jako śmiertelnie poważną i grobową. Nie takim wyobrażam sobie R. Tomaszewskiego w wirze typograficznej pracy, człowieka o niespożytej energii i inwencji. Gdyby chociaż przywoływane reprodukcje pierwszych stron niektórych zeszytów pozostawiono w kolorze, albo w inny sposób zaakcentowano pochodzenie artykułów z zeszytów o różnych kolorach wyróżniających, byłaby ta antologia (tak przypuszczam) przystępniejsza w odbiorze. Pamiętajmy jednak, że jest to całkowicie subiektywne odczucie, a pod względem formalnym i estetycznym publikacji tej niczego zarzucić nie można.

Jeżeli widzę jakiekolwiek niedociągnięcia, które nie są li tylko postulatem, sugestią, życzeniem, lecz faktycznie uchybiają dziełu, to są to wyłącznie dwa drobiazgi. Do żywej paginy wznowienia artykułu Stary grotesk akcydensowy na nowych podstawach Karla Gerstnera zakradł się błąd (ostatni wyraz w paginie urywa się dywizem: „podst-”). Z kolei ilustracja na okładce (il. 4) nigdzie nie została podpisana, przez co dla osób nie znających „Litery” w oryginale lub gorzej zorientowanych w procesie powielania liternictwa drukarskiego może ona wyglądać na zupełnie niezrozumiały bohomaz. Tymczasem jest to ilustracja zatytułowana Przykład ruchliwości znaków z artykułu „Diatype” R. Tomaszewskiego ${ }^{54}$, która ilustruje możliwości kształtowania znaków literniczych fotoskładu przy użyciu aparatu Diatype. Co więcej, artykułu nie włączono do antologii, toteż nie można tego zabiegu rozważać jako gry z czytelnikiem w uważną lekturę. Tym samym bez sięgnięcia do oryginalnego tekstu nie mamy szans ustalić źródła i sensu tej ilustracji, co obniża jej walor.

54 R. Tomaszewski, ,,Diatype”, „Litera” 1968 (R. 3), 1 (19), s. 10. 
Fot. 5. Porównanie artykułu Alberta Kapra Anatomia liter łacińskich $\mathrm{w}$ wersji oryginalnej i przeredagowanej na potrzeby antologii. Źródło: opracowanie własne. Zdjęcie: W. Sierżęga

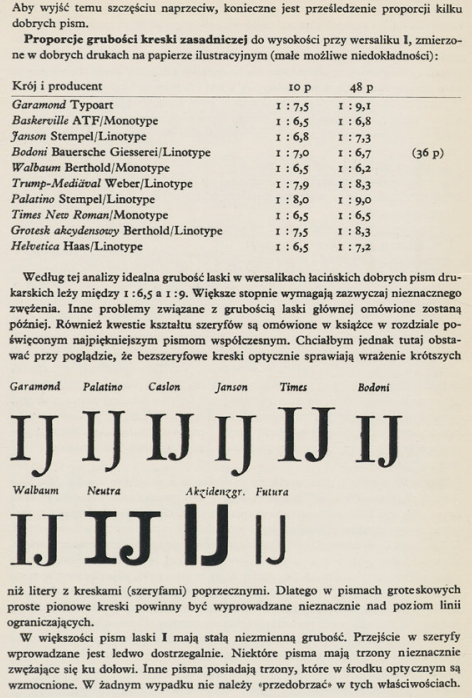

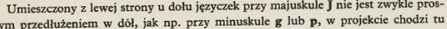

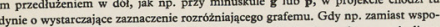
mnianego przedłužnnia w dó, poprowadzimy J u dołu polokreggiem w lewo, to taka litere

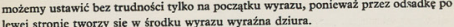

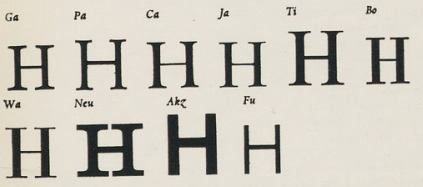

Wersalik H. Rysunek litery $\mathbf{H}$ nasuwa dwa pytania. Jedno brzmi: jak düy powinien być odstęp między droma pionowymi trzonami? Drugie pytanic: iak gruba jak wysoko powinna bye osadzona kreska poilo artystycznych zamierzen projecktanta i od prowa dzenia érzin (cakran pisma. Antyktua jenson posiada najszersc H, kxorego z: 10 ; w bodonim zachowana jest proporcia 6,9 : ro. Krój bodoni i wszystkie klasycystycznc pisma maja względnie wąskie H. (Szeroko biegnace i wąskie warianty pism nie byly tu brane pod uwage). Możemy caryzykowaé definieje, że $\mathbf{H}$ ma dobra szerokobsc, jehl zewnetrzne ogranicenie obydwóch trzonów wynosi ca 8 / Io wysokoseci.

Jak wysoko powinna być osadzona w wersaliku $H$ kreska poprzeczna? W żadnym wypadku w geometrycznym śodku, który można wyznaczyé przymiarem. Tak osa-

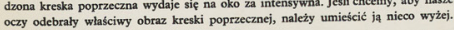
Zjawisko to odnosi się do wielu liter.

Jaka ma byé grubosc kreski poprzecznej? We wspótczesnych replikach dawnych pism renesansowych kreska poprzeczna posiada wiecei niz polowe grubosei kreski rasadniczec, a w oryginale jensona nawet $2 / 3$ grubosci trzonu pionowego. Natomiast w pismach klasycystycanych grubośc kreski wynosi $1 / 8$ kreski zasadnicze; a nickicdy

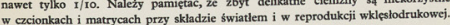
W grotesku naležy takze wriqé pod uwage jeszcze jedno ważne zludzenie optyczne, ì belki poziome stwarzają wrażenie grubszych niż pionowe. Jesli w grotesku kreska pionowa i pozioma optycanie daja wrazenie jednakowo grubych, to kreski
poziome moga micć $w$ zasadzie tylko 9 I Io grubosci kresek pionowych. pochodnych. Można je podzielié na trzy

grupa liter z poziomymi i pionowymi kreskami: I, H, L, E, F, T, J,

grupa liter zaokragglonych:

$\mathrm{O}, \mathrm{Q}, \mathrm{C}, \mathrm{G}, \mathrm{D}, \mathrm{U}, \mathrm{B}, \mathrm{P}, \mathrm{R}, \mathrm{S}$

grupa liter ze skośnymi kre

Porównając koła, trójkąty i kwadraty

zwracamy uwage na nieskomplikowane

optyczne odrębności i na pewne złudze-

nia optyczne dotyczące wszystkich lero-

jów pism. Jeśli koło i tró́kkąat, przy pomo-

cy schematycznego rysunku, sprowadz

się do wysokości kwadratu, wtedy wy wołują wrażenie znaków zbyt małych. Aby zlikwidowac to wrazzenie, koło mu wybiegaću u góry i u dołu, a tró́kąt wystawać swoim wierzchołkiem poza line ograniczające poziomy. W kole dodaje ce u góry okolo $2 \%$ wysokosci wersalika $\mathrm{H}$ 2\% u dofu. W troj lącie rownobocznyn me pon exp nię pomocnicz, nawet do $3 \%$. Naturaln w takim praypadka zaokraglenia nieco w trójką̧̨ach równobocznych odbiegają

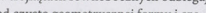
od czysto geometrycznej formy i cze whe wazdy pay de wrazenie optyczne.

MAJUSKULY I oraz I. Jakie problemy nastręcza prosta pionowa kres projektanta pism wersalik Ijest litera kluczowa Rysujac te literę należy okreśślić grubość kreski głównej ilini pomocniczych wszystkich pozostaity Grubość kroju pisma wynika z estetycz
Albert Kapr

nego wyważenia i uchwycenia właściwe proporcji grubości kresek zasadniczyd stosunku do wysokosci H. Kaligrafowie Renesansu usilowali wprowadzic roporcje oparte na anatomii cztowieka, teorego idealna proporcja wysokośsi głoa mic mnicj wieccej jak 1 : 8. Felice Feliciano, thy w roku 1460 jako pierwszy badat 作 cjach, podal trochę inne proporcje, kości miała sie jak 1:10. Zbyt delikatn w rysunk się ak 1:10. Zbyt delikatne pajęczyny. Żle sie nimi rrukowało na . że nie nadają się również do reprodukowania techniką volkestodrukową. Z byt grube pismo podstawowe sprawia zaś  złożonego wymagało wysiłku głosowego. Zdaniem doswiadczonych sztycharzy tia szczésia Aby wyjét stią szczę̧dia. Aby wyjsc temu szczę̧́ci naprzeciw, możemy przesledzić propor

Poporje grabost kreski zasadniczer do mysoksci majuskuly l, mierzone pierze (możliwe małe niedokladności):

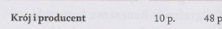

\begin{tabular}{lll}
$\begin{array}{l}\text { Garamond } \\
\text { (Typoart) }\end{array}$ & $1: 7,5$ & $1: 9,1$ \\
\hline
\end{tabular}

\begin{tabular}{l}
$\begin{array}{l}\text { Easkerville } \\
\text { (ATT/Monotype) }\end{array}$ \\
\hline
\end{tabular}

Janson
(Stempel/Linotype)
Anatomia liter łacińskich

\begin{tabular}{|c|c|c|c|}
\hline & & & \multirow{8}{*}{ 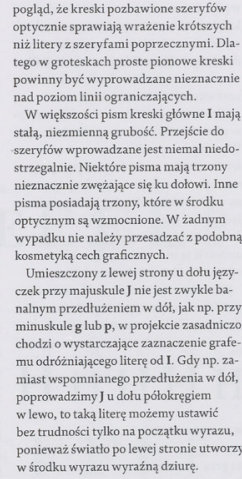 } \\
\hline & & & \\
\hline & & & \\
\hline & & & \\
\hline & & & \\
\hline & & & \\
\hline & & & \\
\hline \multicolumn{3}{|c|}{ 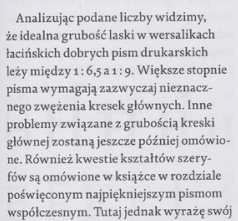 } & \\
\hline
\end{tabular}

IJ IJ IJ IJ IJ IJ IJ IJ IJ IJ

MA|USKUtA H. Rysunek litery $\mathbf{H}$ nasuwa dwa pytania: - Jak duży powinien mi trzonamiz jak gruba i jak wysoko powinna być osadroma kreska pozion Odpowiedź na nie uzależniona jest od adpowiedź na nie uzalezniona jest od prowadzenia duktu kroju pisma. Antykwa Jenson posiada najszersze $\mathrm{H}$, wych trzonów w proporcii do wysokoości litery wynosi 9 : 10, w kroju Bodoni zachowana jest proporcja $6,9: 10$. Bodoni i inne klasycystyczne pisma mają względnie 
Czasopismo „Litera” (1966-1978) jako świadectwo XX-wiecznego dorobku...

Fot. 6. Porównanie artykułu Dirka Wendta Kryteria oceny czytelności pisma$\mathrm{W}$ wersji oryginalnej i przeredagowanej na potrzeby antologii.

Źródło: opracowanie własne. Zdjęcie: W. Sierżęga

\begin{tabular}{|c|c|c|}
\hline $\begin{array}{l}\text { Możliwości usprawn } \\
\text { przy } \\
\text { wysyłającym }\end{array}$ & przy kanale & $\begin{array}{l}\text { przy } \\
\text { odbiorcy }\end{array}$ \\
\hline $\begin{array}{l}\text { uksztaltowanie } \\
\text { graficzne } \\
\text { typografia w szerokim } \\
\text { znaczeniu }\end{array}$ & $\begin{array}{l}\text { warunki } \\
\text { oświetlenia, } \\
\text { kąt widzenia }\end{array}$ & $\begin{array}{l}\text { wychowanie od szkoly } \\
\text { podstawowej aż do } \\
\text { dynamicznego czytania }\end{array}$ \\
\hline $\begin{array}{l}\text { manipulowanie przy } \\
\text { badaniu czytelności }\end{array}$ & & $\begin{array}{l}\text { doświadczenie } \\
\text { przyniosło nawyki }\end{array}$ \\
\hline
\end{tabular}

2̇ycia na systematyczne badanie wplywu poszczególnych cech pisma na czytelność, a swoje doświadczenia opisal w serii artykulów $i$ ksiažck. Nicco późnicj ukazaly sic gadnien ja nie mam tu nic do dodania.

Badania a doświadczenia praktyczne

Wyniki doswiadezen naukowych w znacznym stopniu pokrywaja się z codriennymi dosviadezeniami praktyków. Dla normalnego ciaglego telstu czytelniczego podaje się stale wielkość około 10 p., jako zakres optymalnej wielkości pisma. Jeśli chodzi o szerokość składu, to zasieg optymalnej szerokości wiersza

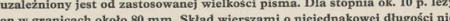
jest granicach tolo ed składu z wyrównanym prawym marginesem.

Procentowe odchylenia przeciętnej prędkości czytania dla poszczególnych pism od średniej ogólnej wartości 1153,22 wyrazów 3 minuty

\begin{tabular}{clrrrr}
\multicolumn{2}{c}{ krój pisma } & cienki & zwykly & pólgruby & gruby \\
\multirow{2}{*}{ bodoni } & proste & +4.06 & +1.97 & +0.51 & -2.56 \\
& kursywa & +0.68 & -0.27 & -1.78 & -5.60 \\
\multirow{2}{*}{ futura } & proste & -0.20 & +1.84 & +1.27 & -3.53 \\
& kursywa & +2.94 & +2.54 & +0.89 & -2.74 \\
\hline
\end{tabular}

Odchylenia powyżej $2,5 \%$ bẹdą wysteppować na podstawie przy-

padkowości w próbie

\begin{tabular}{|c|c|c|c|c|}
\hline \multicolumn{5}{|c|}{$\begin{array}{l}\text { Procentowe odchylenia przeciętnej prędkości czy- } \\
\text { tania od średniej wartości dla } 18 \text { cicer długości } \\
\text { wiersza z } 2 \text { p. interlinią wg Tinkera } 1963 \text { r. }\end{array}$} \\
\hline Interlinia: & $0 \mathrm{p}$. & $1 \mathrm{p}$. & $2 \mathrm{p}$. & $4 \mathrm{p}$. \\
\hline \multicolumn{5}{|c|}{ Długość wiersza: } \\
\hline 8 cicer & $-9,52$ & $-4,75$ & $-5,76$ & $-6,78$ \\
\hline 14 cicer & -439 & $+0,68$ & $+0,46$ & $+1,30$ \\
\hline 18 cicer & $\begin{array}{r}-2,72 \\
-5,17\end{array}$ & $\begin{array}{r}+0,23 \\
+0,5\end{array}$ & $\begin{array}{r}0,00 \\
+243\end{array}$ & $\begin{array}{r}+3,24 \\
+0,40\end{array}$ \\
\hline $\begin{array}{l}30 \mathrm{cicer} \\
40 \text { cicer }\end{array}$ & $\begin{array}{l}-5,17 \\
-5,83\end{array}$ & $\begin{array}{l}-0,45 \\
-3,97\end{array}$ & $\begin{array}{r}+2,43 \\
-5,81\end{array}$ & $\begin{array}{l}+0,40 \\
-2,57\end{array}$ \\
\hline
\end{tabular}

Wartość kursywna ksztaltuje się na poziomie $1 \%$, tzn. tak duże lub jeszcze wiekssze odchylenia bẹda wystecpować na podstawic przypadkowości w próbie
przypadków lub rzadziej.

Bezszeryfowe pisma nie sq mniej czytelne niż pisma z szeryfami, a w zasadzie wszystkie powszechnie stosowane tzw. pisma normalne, np. dzielowe, dają się caytac

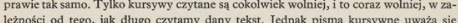

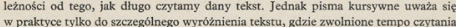
w wiẹkszości przypadków jest zamierzone, aby czytelnik mógl zatrzymaés się cokolwiek

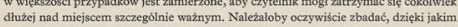
śodkom typograficznym najlepiej osiqgnąc można takie celowe zwolnienie szybkosci czytania.

To jest przykład, jak skoki okà moga przebiegaé przy czytaniu, Kola wskazuią ostro widzialne części fiksacji, linie kreskowane skoki na prźód, przecíaghięte skoki wstèGzre.
47(5) Kryteria oceny czytelności pisma

1971

Ustalenic jednoznacznych kryteriów czytenosci pism drukarskich jest wciąz bard otrudne. Wptywa na to stosowarnie róz:nych wspotccynnnikót zależnosci $i$ ocenic wymaga dalszych badari i doswiadczeń wymaga dalszych badan i doswiadczen Faworyzowanie dawnej typografii prowadzi do subiektywizowania wyników bada Przy nowych badaniach należy postawić pytanie: dobrze czytelne - do czego?

Jeśli czytanie uważać za techniczny proces komunikacji, w którym za pośrednictwem drukowanego tekstu przekazane mają być informacje od wysyłającego do czytelnika-odbiorcy, to zagadnienie czytelności może wyłonić się też jako problem przepustowości
kanału. Ile možna przekazać informacj w danej jednostce czasu przez kanał czytanie? Cechy, które moglyby sprzyjać
lub przeszkadzać w tej przepustowości kanałów, zatem kryteria czytelności, można umieścić po obu stronach kana $\mathrm{Z}$ jedncj będą to kryteria wspónych cech ocenianego pisma, jak np. wysteppowan lub brak szeryfów, proporcje górnych i dolnych wydłużeń do wysokości zna ków krótkich, grubość kreski, wzglẹdne wypehnianie wiersza itd. $Z$ drugiej strony kanału pod kryteriami czycelności rozumieć równicź można cechy postẹpowania 240 obserwować i rejestrować, aby z nich. późnicj wyciągnąć z nich wnioski o czy telności pisma czytanego przez badaneg osobrik

Chọ się pokusić o omówienie obydwóch pojećk kryteriów, choć, co prawda, na wymienione na pierwszym miejscu kryterium cyytelności określonego pisma man niewiele do powiedzenia. Miles A. Tinker poświęcił dziesiątcí lat życia na systematyczne badanie wpływu poszczególnych cech pisma na czytelność, a swoj doświadczenia opisał w serii artykutów i książek. Nieco później ukazały się publikacje Brora Zachrissona i Herberta Spencera. W zakresie poruszonych tan zagadnieŕ ja nie mam nic do dodania.

BADANIA A DOŚWIADCZENIA

PRAKTYCZNE

Wyniki badań naukowych w znacznym stopniu pokrywają sie z codziennymi doświadczeniami praktyków. Dla normalnego ciagłego tekstu czytelniczego podaje się stale wiellkość około $10 \mathrm{p}$. . jako zakres optymalnej wielkości pisma. Teśli chodzi o szerokosć składu, to zasię optymalnej dtugości wiersza uzależnion jest od zastosowanej wielkości pisma. Dh stopnia ok. $10 \mathrm{p}$. leży on w granicach ok $80 \mathrm{~mm}$. Sklad wierszami o niejednakowej długości nie jest gorzej czytelny od składu z wyrównanym prawym marginesem. Bezszeryfowe pisma są nie mniej czy dzie wszystkie powszechnie stosowane
Kryteria oceny czytelności pisma

tzw. pisma normalne, np, driełowe, dają się czytać prawie tak samo. Tylko kursywy czytane są cokolwiek wolniej i to coraz wolniej, w zależności od tego, jak długo czytamy dany tekst. Jednal pisma kursywne uzywa siç w praktty ce tylko do szezegong go wyrozzienia

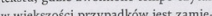
w więkssosci przypad ju joor zamecolwiek dhice nad miejecen sycer colve gônie wažny Nalezaloby oczywisc

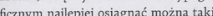
ficznym najlepiej osiagnią́ można tal Wesyskkie wymienione wyilki bast drito dziatają na prakt,yka niczwykc uspo

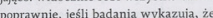
Popran ruie siẹ optymalnie dobra, co równiéz petwiendzij przeprowadzone analizy naukowe. Wydaje się zatem, że dalsoe badania sa zbyteczne. W trakcie bad zaobserwowano jednak szereg ziawisk dodatkowych, które wskazywaty na to. ze pozory mogą mplić. Okazało się na przyktad, je czytelnik może czytać jakieś pismo coraz szybciej i to tym szybciej, im dłużej czyta tekst składany tym pismem - nawet gdyby pismo to początkowo nie było szczególnie dobrze czytelne. Czytajacy widocznie moze szyb praywylkną́ do pisma i w nastepstwie lepiej je przyswaja, nawet wtedy, gdy na wsteppie czytanie sprawiało mu trudność. Prowadámy dalej te rozwa żania i zastanówmy się nad wynikam a nasuną sie nam wkrótce watpliwość, o których dotychczas mówiono.
PRZYZWYCZAIENIA TYPOGRAFICZN Možliwe, że zunifikowana typografia naszych książek, czasopism igazet nie jest weale najlopsza. Wyajo de nam on mentach, porit doswi pon jo siç z taka znormalizowana typografiaz co dzień. Zd żyli już do niej przywykna

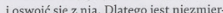
nie trudno rozwiazać te problemy na drodze empiryczrnych doświadczeń Prawdopodobnie nienoiliwe bytaby prayzwycajenie caytenika wy traby eksperymentów do jakiejśs określonej nowej typografii, driekcilktórej uzyskat th on cała poprzednią biegosość. Zdaje sie. że nie byłoby również możliwe dolkładn sprawdzenic poprzedniej bicçóci u os poddawanych doswiadczeniu, chyba ṫe w innych grupach kulturowych (np. Chińczycy lub Japończycy), które pism lacińskie poznaty dopiero w trakcie nauki jgzyka obcego. Możliwe byłoby przeprowadzenie eksperymentu w kilku równolegtych grupach, przy czym każd z grup otrzymałaby od razu materia do czytania tylko w jednej określon typografii. Tak uzyskane wyniki bylyby jednak dla naszej kultury ponownym, wątpliwej wartoșci generalizowanie

WPEYW GROTESKU NA

PRZYZWYCZAJENIA TYPOGRAFICZN Od kilku lat zaobserwować można w typografii zwiększzające się stosowanic pism jednoelementowych - grotesków. początikowo wykorzystywano grotesk w czasopismach, teraz także w niektó- 


\section{Podsumowanie}

Litera służ porozumieniu to tytuł artykułu R. Tomaszewskiego z 1978 r., ostatniego roku ukazywania się „Litery”, którego wznowienie zamyka tekst główny antologii. Taki też jest cel typografii i liternictwa drukarskiego unaoczniać komunikację, ucieleśniając i utrwalając ją w czasie i przestrzeni dla jej współczesnych i przyszłości. Dlatego też teksty z „Litery” zebrane $\mathrm{w}$ antologii nadal są aktualne, dlatego też powinny być przywoływane i powtarzane - ponieważ

zawartość „Litery” uwzględnia przenikające się wzajemnie aspekty: estetyczny, techniczny i społeczny. Pismo - genialny wynalazek cywilizacji - oraz jego praktyczna liternicza interpretacja właśnie tak funkcjonują w naszej rzeczywistości, w której potwierdzają swa użyteczność w każdej dziedzinie życia ${ }^{55}$.

Toteż z tym większym ubolewaniem podaję na zakończenie analizy tego fragmentu dwudziestowiecznego dorobku polskiej myśli o typografii i liternictwie, że antologia „Lit[t]tera Romana” ukazała się w nakładzie jedynie 500 egzemplarzy, który w dodatku był niedostępny w handlu księgarskim (umowa grantowa zakładała, że jest to materiał niekomercyjny i tym samym niesprzedażny), choć można było ją pozyskać jako darmową pozycję u wydawcy (Polsko-Japońskiej Akademii Technik Komputerowych) oraz przy zakupie dowolnej książki z oferty wydawnictwa d2d.pl. Dlatego w ogóle nie dziwi, że w tej chwili jest już niedostępna. Pozostaje więc na pocieszenie dodać, że według Narodowego Uniwersalnego Katalogu Centralnego (stan na 10 VI 2021) jest już obecna w księgozbiorach Lublina, Łodzi, Poznania, Szczecina, Torunia, Warszawy i Wrocławia. Teraz wypada już tylko zaprosić do tej pożytecznej lektury.

\section{Bibliografia}

Angielsko-polski leksykon terminów poligraficznych, pod red. L. Markowskiego, Warszawa 2013.

Chamera-Nowak A., Roman i Andrzej Tomaszewscy w niewoli książek, [w:] W poszukiwaniu odpowiedniej formy. Rola wydawcy, typografa, artysty $i$ technologii w pracy nad książka, pod red. M. Komzy przy współudz. E. Jabłońskiej-Stefanowicz, E. Repucho, Wrocław 2012, s. 217-231.

Kowalik E., „Litera” (1966-1974). Dodatek do „Poligrafiki”, [praca magisterska napisana pod kierunkiem doc. dr hab. H. Tadeusiewicz w Katedrze Bibliotekoznawstwa i Informacji Naukowej Uniwersytetu Łódzkiego], 1984.

[Kowalska B.], Weryfikacja pism, nowe zamiary, „Litera” 1967, (R. 2), nr 9 (17), 142-143.

55 A. Tomaszewski, Wprowadzenie..., s. 14. 
[Kowalska B.], Wnioski po pięciu naradach, „Litera” 1966, (R. 1), nr 8, s. 116-119.

Kowalska B., Wybór asortymentu czcionek, „Litera” 1966, (R. 1), nr 7, s. 102-109.

Lit(t)era Romana. Antologia tekstów z czasopisma ,Litera” 1966-1978, oprac. M. Marek-Łucka, A. Tomaszewski, Warszawa 2020.

Luberda A., Dyskurs teoretyczny wokół krojów pisma na łamach „Litery. Dodatku do «Poligrafiki» dotyczacego spraw liternictwa, czcionek i matryc drukarskich”, [praca licencjacka napisana pod kierunkiem dr M. Komorowskiej w Katedrze Edytorstwa i Nauk Pomocniczych Uniwersytetu Jagiellońskiego], 2016.

Luberda A., ,Litera” Romana Tomaszewskiego. Pierwsze pismo typograficzne w Polscezarys historii i przybliżenie tematyki, „Rubryka” 2017, nr 3, s. 52-66, [online] issuu. com/kneuj/docs/rubryka_3 [dostęp 28.05.2021].

Monika Marek-Łucka, [online] snm.pja.edu.pl; snm.pja.edu.pl/project/monika-marek-luc$\mathrm{ka} /$ [dostęp 7.06.2021].

Marek M., Misja „Litera”, „2+3D” 2012, nr 3 (44), s. 50-55.

Nihon no rogo māku 50-nen. Nihon taipogurafi nenkan 40-satsu yori besuto sakuhin 100ten no ākaibu, Nihon Taipogurafi Kyōkai, Tōkyō 2020.

O nas, poligrafika.pl, [online] poligrafika.pl/o-nas-3/ [dostęp 26.05.2021].

Repucho E., Acta Poligraphica. Czasopismo naukowe poświęcone poligrafii, 2013, R. 1, wol. 1 [recenzja], „Roczniki Biblioteczne” 2013, nr 57, s. 178-182.

Repucho E., Estetyka zaangażowana. Rola „Poligrafiki” w podnoszeniu poziomu estetycznego polskiej produkcji wydawniczej w latach 1947-1956, „Acta Universitatis Wratislaviensis. Bibliotekoznawstwo" 2008, nr 27, s. 77-96.

Sobocińska A., Tomaszewski A., Bibliografia prac poligrafa, wydawcy i bibliofila Romana Tomaszewskiego (1921-1992) za lata 1948-1994, [w:] Studia o ksiażce dawnej i wspótczesnej, pod red. I. Imańskiej, J. Tondela, Toruń 2006, s. 37-71.

Socha K., Z dziejów drukarstwa polskiego. Cykl artykułów z „Biuletynu Poligraficznego”, „Acta Poligraphica” 2020, nr 16, s. 43-74.

Sowula G., Roman, „Notes Wydawniczy” 2002, nr 12, s. 68-69.

Szydłowska A., Misiak M., Paneuropa, Kometa, Hel. Szkice z historii projektowania liter w Polsce, Kraków 2015.

Szymański K., Systemy miar w typometrii, „Przegląd Papierniczy” 2012, (R. 68), nr 4, s. 211-214, 216.

Świątek R.S., Szukającym wiedzy i prawdy, czyli naukowo o poligrafii, „Sztuka Edycji” 2013, nr 5, s. 154-156.

Tomaszewski A., Architektura książki dla wydawców, redaktorów, poligrafów, grafików, autorów, księgoznawców i bibliofilów, Warszawa 2018.

Tomaszewski A., Bibliografia zawartości „Litery” R. 1:1966-R. 9:1974, „Litera” 1974, nr 2 (57), s. 107-116.

Tomaszewski A., Giserzy czcionek w Polsce. Poczet odlewaczy czcionek działajacych w dawnej Polsce oraz polskich za granica, Warszawa 2009.

Tomaszewski A., Leksykon pism drukarskich, Warszawa 1996. 
Tomaszewski A., Ośrodek Pism Drukarskich w Warszawie (1968-1979), „Acta Poligraphica” 2020, nr 15, s. 49-67.

Tomaszewski A., Pismo drukarskie, pod red. H. Janowskiego, Wrocław 1989.

Tomaszewski A., „Pro Typo” - zapomniane czasopismo zawodowe, „Acta Poligraphica” 2019, nr 14, s. 41-54.

Tomaszewski A., Tomaszewski Roman, [w:] Słownik pracowników książki polskiej. Suplement 2, pod red. H. Tadeusiewicz z udziałem B. Karkowskiego, Warszawa 2000, s. 163.

Tomaszewski A., Wprowadzenie do lektury, [w:] Lit(t)era Romana, oprac. M. Marek-Łucka, A. Tomaszewski, Warszawa 2020, s. 9-15.

Tomaszewski R., ,Diatype”, „Litera” 1968, (R. 3), 1 (19), s. 6-11.

Tomaszewski R., Klasyfikacja pism drukarskich ART, [w:] Z badań nad dawna książka. Studia ofiarowane profesor Alodii Kaweckiej-Gryczowej w 85-lecie urodzin. T. 2, [kom. red. P. Buchwald-Pelcowa i in.], Warszawa 1993, s. 663-676.

Tomaszewski R., Materiały do bibliografii na temat Czytelności pism drukarskich, Warszawa 1973.

[Tomaszewski R.], Program szkolenia redaktorów. Studium techniczno-wydawnicze. Cz. 1, Warszawa [1956].

Tomaszewski R., Stan i potrzeba rozwoju liternictwa drukarskiego, „Litera” 1974, nr 2 (57), s. 51-60.

Tomaszewski R., Typometria, cz. 1-8, „Poligrafika” 1980, (R. 32), nr 4, s. 104-106, nr 5, s. 135-136, nr 7, s. 191-192; 1981, (R. 33), nr 3, s. 69-70, nr 5-6, s. 134-135, nr 7-8, s. 166-167; 1982, (R. 34), nr 1, s. 31-33, nr 3, s. 100-101.

Tomaszewski R., Typometria pism drukarskich, „Litera” 1967, (R. 2), nr 3 (11), s. 41-44.

Tomaszewski R., Typograficzny system calowy i uniwersalny, „Litera” 1967, (R. 2), $\mathrm{nr} 4$ (12), s. 59-61.

[Zdrojewska I.] IZ, Edytor, typograf, bibliofil, erudyta, „Poligrafika” 2003, nr 3, s. 76-77.

Zdrojewska I., Od Alphabetum Romanum do pism komputerowych. „Lit(t)era Romana”, „Poligrafika” 2021, (R. 73), nr 1, s. 60-61. 